\title{
Unraveling the complex local-scale flows influencing ozone patterns in the southern Great Lakes of North America
}

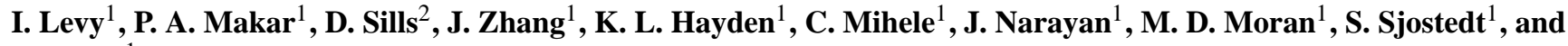 \\ J. Brook ${ }^{1}$ \\ ${ }^{1}$ Air Quality Research Division, Science and Technology Branch, Environment Canada, 4905 Dufferin Street, Toronto, \\ Ontario, Canada \\ ${ }^{2}$ Cloud Physics and Severe Weather Research Section, Environment Canada, 4905 Dufferin Street, Toronto, Ontario, Canada
}

Received: 9 July 2010 - Published in Atmos. Chem. Phys. Discuss.: 23 August 2010

Revised: 2 November 2010 - Accepted: 15 November 2010 - Published: 22 November 2010

\begin{abstract}
This study examines the complexity of various processes influencing summertime ozone levels in the southern Great Lakes region of North America. Results from the Border Air Quality and Meteorology (BAQS-Met) field campaign in the summer of 2007 are examined with respect to land-lake differences and local meteorology using a large array of ground-based measurements, aircraft data, and simulation results from a high resolution $(2.5 \mathrm{~km})$ regional airquality model, AURAMS.

Analyses of average ozone mixing ratio from the entire BAQS-Met intensive campaign period support previous findings that ozone levels are higher over the southern Great Lakes than over the adjacent land. However, there is great heterogeneity in the spatial distribution of surface ozone over the lakes, particularly over Lake Erie during the day, with higher levels located over the southwestern end of the lake. Model results suggest that some of these increased ozone levels are due to local emission sources in large nearby urban centers. While an ozone reservoir layer is predicted by the AURAMS model over Lake Erie at night, the land-lake differences in ozone mixing ratios are most pronounced during the night in a shallow inversion layer of about $200 \mathrm{~m}$ above the surface. After sunrise, these differences have a limited effect on the total mass of ozone over the lakes and land during the day, though they do cause elevated ozone levels in the lake-breeze air in some locations.

The model also predicts a mean vertical circulation during the day with an updraft over Detroit-Windsor and downdraft over Lake St. Clair, which transports ozone up to $1500 \mathrm{~m}$ above ground and results in high ozone over the lake.
\end{abstract}

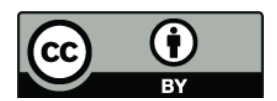

Correspondence to: J. Brook (jeff.brook@ec.gc.ca)
Oscillations in ground-level ozone mixing ratios were observed on several nights and at several ground monitoring sites, with amplitudes of up to $40 \mathrm{ppbv}$ and time periods of 15-40 min. Several possible mechanisms for these oscillations are discussed, but a complete understanding of their causes is not possible given current data and knowledge.

\section{Introduction}

Land and sea/lake breeze winds play an important role in determining many aspects of coastal environments, and air quality in particular. Air pollutants levels in coastal regions, that hold a large part of the world's population along with emission sources, are the outcome of the combined effect of several factors, such as long-range transport, short-range transport, local emissions, photochemical activity, and surface properties (Banta et al., 2005). While the main driving force of the breeze winds is the time-varying temperature difference between land and sea/lake, other factors have been shown to interact with these winds, such as large-scale synoptic flow (e.g., Oh et al., 2006), the urban heat island (e.g., Ohashi and Kida, 2002), vicinity to a mountain ridge (e.g., Lu and Turco, 1994), curvature of the shoreline (e.g., Alpert and Getenio, 1988; Levy et al., 2008b), and other topographical features such as vegetation, land use and land cover.

The effect of sea/lake breeze winds on air pollution has been shown in many locations around the world, such as Athens (e.g., Kallos et al., 1993; Kambezidis et al., 1998); the Iberian peninsula (Millan et al., 2000); southern France (e.g., Lasry et al., 2005); Israel (e.g., Alper-Siman Tov et al., 1997; Levy et al., 2008a); Taiwan (e.g., Cheng, 2002; Liu et al., 2002); Korea (Oh et al., 2006), southwestern British

Published by Copernicus Publications on behalf of the European Geosciences Union. 
Columbia (Brook et al., 2004), and Los Angeles (Lu and Turco, 1994, 1995). The large populations living in these coastal cities are often exposed to high pollution levels due to higher emissions and may experience greater health impacts due to higher chronic exposures accentuated or even induced by the complex local meteorology. Thus, this meteorology can lead to more complex yet potentially repeatable exposure patterns.

The impact of the North American Great Lakes on pollution levels has been studied since the 1960's (e.g., Mukammal, 1965; Lyons and Cole, 1973, 1976; Anlauf et al., 1975; Keeler et al., 1990; Sillman et al., 1993; Dye et al., 1995; Hanna and Chang, 1995; Hastie et al, 1999; Cooper et al., 2001; Fast and Heilman, 2003, 2005). These multi-year observations combined with model output suggest that ozone is systematically higher over the lakes. Dye et al. (1995) analyzed observations from the Lake Michigan Ozone Study in 1991, and found the highest ozone concentrations occur in a shallow and cool conduction layer over the lake. Ozone precursors emitted during the night and early morning were trapped in this shallow layer of cool and stable air over the water to react and produce high concentrations of ozone during the day. Hastie et al. (1999) reported increases of $30 \mathrm{ppbv}$ in ozone levels measured in air masses arriving with the Lake Ontario lake-breeze front, measured at two ground stations north of the lake and from an aircraft. The authors postulate that the origin of these polluted air masses is emissions from source areas that are entrained over the lake by the land breeze at night. Fast and Heilman (2005) used the PEGASUS air-quality model to evaluate ozone levels over the Great Lakes region for two summers (May-September 1999 and 2001). Ozone exceedances above 60 and $80 \mathrm{ppbv}$ were found to be higher on average over the southern Great Lakes than over land. Similar findings were published by Capps et al. (2010) for a 14-day period in August 2002 using the CMAQ air-quality model.

The magnitude of the land-lake differences in ozone are not well characterized due to a lack of routinely available pollutant data of fine spatiotemporal resolution. For example, Hastie et al. (1999) reported that ozone levels ranged from $60 \mathrm{ppbv}$ to $100 \mathrm{ppbv}$ over Lake Ontario during measurements with an instrumented aircraft on 26 August 1993 around noon, while $\mathrm{NO}_{\mathrm{x}}$ ranged from $1.5 \mathrm{ppbv}$ to 6 ppbv. In a subsequent flight about one hour later, ozone levels were within the same range, but the location of the maximum ozone had changed, suggesting that both spatial and temporal changes, perhaps related to advection patterns, play an important part.

During the Border Air Quality and Meteorology (BAQSMet) study, which took place in summer 2007 in southwestern Ontario, Canada, a comprehensive suite of air-quality and meteorological measurements were made from both fixed and mobile platforms in order to study air pollutant transport and transformation in relation to lake and land breezes and to gain more insight into the nature of the high ozone over and near the lake in particular. The study region is situated between two of the Great Lakes, Lake Erie and Lake Huron, and a third, smaller lake, Lake St. Clair (see Fig. 1). This paper describes some of the results from this study that are related to ozone levels over Lake Erie and Lake St. Clair. First, average ozone mixing ratios from ground-level measurements and from the AURAMS regional air-quality model are examined in time and space. Then, a case study is presented to illustrate the influence of local meteorological circulations driven by the southern Great Lakes on air quality. Included in the analysis are measurements from a mesonetwork, a chemistry supersite, an instrumented aircraft, an instrumented ferry, an instrumented buoy, and a tethersonde.

The goal of this paper is to elucidate the complexity of various processes influencing summertime ozone levels in the southern Great Lakes region of North America. More specifically, it examines the spatio-temporal variability in the levels of surface ozone and related air pollutants, with respect to precursors emission sources, regional- (synoptic) and local- (land-lake breeze) scale meteorology, differing processes over land and water, and the vertical structure of ozone. The analyses, which are unique in the extent to which detailed measurements and model applications have been combined and interpreted, provide insight regarding the behaviour and significance of the elevated ozone levels over the complex coastal environment.

\section{Datasets}

The BAQS-Met field campaign was conducted during the summer of 2007 to study the effect of mesoscale meteorology on air pollution in the southwestern Ontario. Figure 1 provides an overview of the study area and measurement station locations used in this paper. In addition to routine airquality monitoring stations operated by the Province of Ontario (Thermo Scientific instrumentation with ozone logged at $1 \mathrm{~min}$ resolution) and the State of Michigan ( $1 \mathrm{~h}$ resolution for ozone), spatial detail was enhanced by deploying a mesonetwork of ozone and meteorological instruments. This was in operation before, during and after the intensive observing period of the study (20 June to 10 July) to obtain $1-5 \mathrm{~min}$ time-resolved measurements for the late spring to late summer period. Ozone mixing ratios at the meso-network sites were measured using low-power monitors from 2B Technologies (Model \#202). Ozone instruments were also installed on a buoy in Lake Erie and on a ferry operating in Lake Erie between Leamington and Pelee Island (Thermo Scientific instrumentation with ozone logged at $1 \mathrm{~min}$ resolution).

Additional detailed chemical measurements were made with research-grade instruments at three chemistry supersites (Harrow, Bear Creek, and Ridgetown) which operated for the intensive period (e.g., Stroud et al., 2010). These sites used instruments from Thermo Scientific to measure 


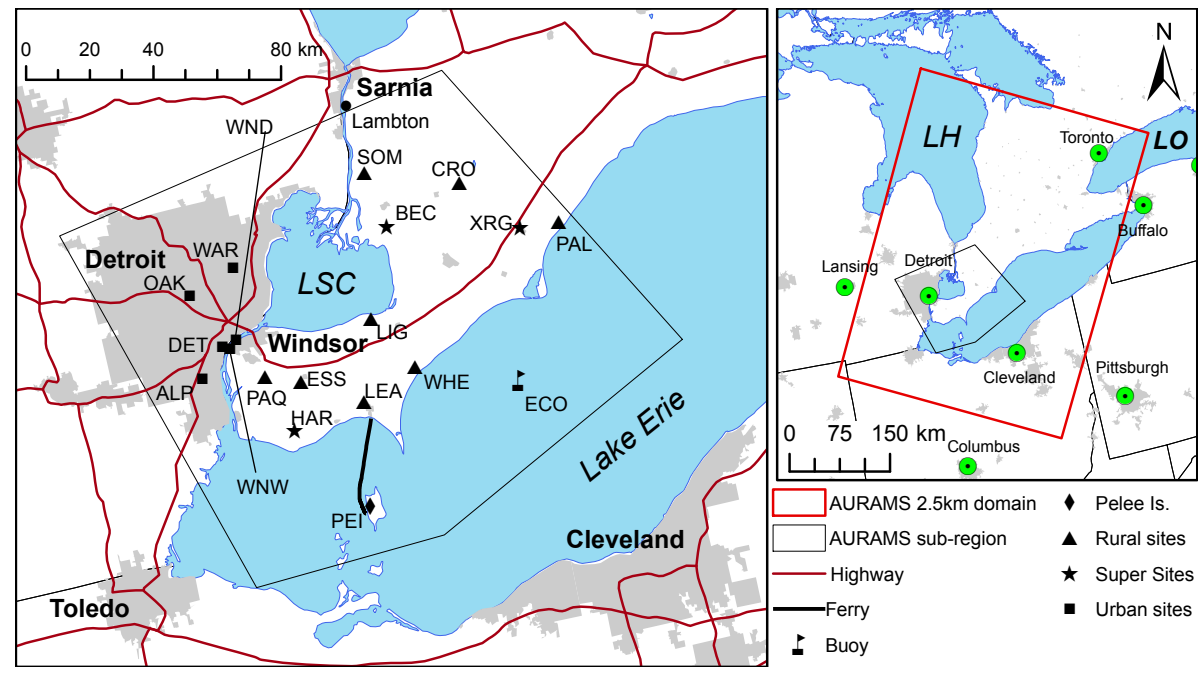

Fig. 1. Map of study region, indicating (left) model analysis sub-domain and the locations of chemistry supersites (BEC - Bear Creek, XRG - Ridgetown, HAR - Harrow), monitoring stations, buoy (ECO), ferry route, and main urban areas (gray shaded regions), and (right) the 2.5-km AURAMS model domain and larger setting. LSC marks Lake St. Clair; LH marks Lake Huron, and LO marks Lake Ontario.

$\mathrm{O}_{3}$ (Model 49C), $\mathrm{SO}_{2}$ (Model 43C), $\mathrm{CO}$ (Model 48 TLE) and $\mathrm{NO} / \mathrm{NO}_{\mathrm{x}}$ (Model 42C). A standard chemiluminescencebased $\mathrm{NO} / \mathrm{NO}_{\mathrm{x}}$ instrument (Thermo Scientific Model 42C) was modified in-house to conduct continuous measurements of $\mathrm{NO}, \mathrm{NO}_{2}$ and $\mathrm{NO}_{\mathrm{y}}$ with 1 min time resolution. Gas phase volatile organic compounds were measured at Harrow with 5 min resolution by an Ionicon Proton Transfer Mass Spectrometer (PTR-MS) (Gouw and Warneke, 2007). An instrumented Twin Otter aircraft was also deployed for approximately $30 \mathrm{~h}$ of flight time measuring gas and particle phase pollutants as well as meteorology at a $1 \mathrm{~s}$ time resolution. These measurements are described in detail in Hayden et al. (2010). At the Ridgetown supersite, a Vaisala Tethersonde system consisting of three ECC ozonesondes from Science Pump (model 6A) and tethered meteorological sondes (model \# TTS111/RSS911) made measurements from the surface up to about $1000 \mathrm{~m}$ above ground level (a.g.l.) on multiple days during the period.

To better understand the BAQS-Met observations, output from the GEM/AURAMS regional air-quality modeling system (Cho et al., 2009; Côté et al., 1998; Makar et al., 2009), which was run with three nested grids with 42,15 and $2.5 \mathrm{~km}$ horizontal grid spacing (Fig. 1), are also analyzed in this paper. A more detailed description of the model set up and a comprehensive evaluation of the model's performance for BAQS-Met is given by Makar et al. (2010a, b).

The main purpose of the model applications presented here was to obtain a more detailed interpretation of the pollutant behavior in the study region and to assess the prevalence and/or validity of the commonly observed and modeled high ozone levels over the lakes. Although the model has limitations, it also has unique value in providing a complete, physically-consistent, four-dimensional description of the at- mosphere during BAQS-Met that is not possible with measurements. Recognizing the model is imperfect, an attempt is made in this paper to use the model predictions in conjunction with available measurements so as to provide broader insight in a manner that accentuates the model strengths (e.g., long term average fields as opposed to specific measurement periods) and provides complementary information that helps to interpret the measurements. Our focus here has not been to evaluate the model (cf. Makar et al., 2010a, b) but to use it to help understand the conditions in the region, in light of available measurements. Nonetheless, the reader needs to be aware that what is displayed in several cases is model output and we have tried to make this distinction clear in the text. Model output was analyzed with the open-source statistical language R (RDCT, 2009) and visualized with the Unidata Integrated Data Viewer (IDV) (Murray et al., 2003).

Diurnal averages of measured ozone were calculated at 11 rural sites and 6 urban sites, as well as for the Buoy and Pelee Island sites in Lake Erie (shown in Fig. 1, listed in Table 1). For consistency between different sites, averages were calculated for the Buoy operational period only (26 June-10 July 2007). Diurnal averages were created by calculating 2 -h running averages of ozone on a 1-min basis (1-h for Michigan sites) for each site during the entire period, then averaging by time of day for each site. The 2-h period was selected for consistency with Michigan sites. Composite diurnal averages were then obtained by averaging over sites grouped by type, i.e., rural and urban, as described in Table 1. Diurnal change rates in ozone concentration were calculated by hour as the difference between the averages of two consecutive hours. Also, the AURAMS predicted ozone levels for the near-surface layer during the buoy operational period were extracted over a relevant analysis sub-domain around 
Table 1. List of sites used for ozone analysis.

\begin{tabular}{lllrrl}
\hline Name & Abbreviation & Type & Latitude & Longitude & Network \\
\hline Palmyra & PAL & Rural & $42^{\circ} 26.525^{\prime} \mathrm{N}$ & $81^{\circ} 44.370^{\prime} \mathrm{W}$ & MESONet \\
Croton & CRO & Rural & $42^{\circ} 36.571^{\prime} \mathrm{N}$ & $82^{\circ} 04.812^{\prime} \mathrm{W}$ & MESONet \\
Sombra & SOM & Rural & $42^{\circ} 41.780^{\prime} \mathrm{N}$ & $82^{\circ} 25.781^{\prime} \mathrm{W}$ & MESONet \\
Paquette Corners & PAQ & Rural & $42^{\circ} 11.717^{\prime} \mathrm{N}$ & $82^{\circ} 57.922^{\prime} \mathrm{W}$ & MESONet \\
Leamington & LEA & Rural & $42^{\circ} 04.121^{\prime} \mathrm{N}$ & $82^{\circ} 36.826^{\prime} \mathrm{W}$ & MESONet \\
Wheatley & WHE & Rural & $42^{\circ} 07.978^{\prime} \mathrm{N}$ & $82^{\circ} 23.731^{\prime} \mathrm{W}$ & MESONet \\
Lighthouse Cove & LIG & Rural & $42^{\circ} 17.499^{\prime} \mathrm{N}$ & $82^{\circ} 31.343^{\prime} \mathrm{W}$ & MESONet \\
Essex & ESS & Rural & $42^{\circ} 09.600^{\prime} \mathrm{N}$ & $82^{\circ} 50.000^{\prime} \mathrm{W}$ & OME \\
Ridgetown (Supersite) & XRG & Rural & $42^{\circ} 27.200^{\prime} \mathrm{N}$ & $81^{\circ} 53.268^{\prime} \mathrm{W}$ & OME \\
Harrow (Supersite) & HAR & Rural & $42^{\circ} 01.978^{\prime} \mathrm{N}$ & $82^{\circ} 53.603^{\prime} \mathrm{W}$ & EC ${ }^{2}$ OME \\
Bear Creek (Supersite) & BEC & Rural & $42^{\circ} 32.153^{\prime} \mathrm{N}$ & $82^{\circ} 23.352^{\prime} \mathrm{W}$ & OME \\
Pelee Island & PEI & Lake & $41^{\circ} 46.767^{\prime} \mathrm{N}$ & $82^{\circ} 40.220^{\prime} \mathrm{W}$ & OME \\
Lake Erie Buoy & ECO & Lake & $42^{\circ} 02.005^{\prime} \mathrm{N}$ & $82^{\circ} 59.006^{\prime} \mathrm{W}$ & IADN \\
Windsor Downtown & WND & Urban & $42^{\circ} 18.983^{\prime} \mathrm{N}$ & $83^{\circ} 02.664^{\prime} \mathrm{W}$ & OME \\
Windsor West & WNW & Urban & $42^{\circ} 17.567^{\prime} \mathrm{N}$ & $83^{\circ} 04.400^{\prime} \mathrm{W}$ & OME \\
Allen Park & ALP & Urban & $42^{\circ} 13.700^{\prime} \mathrm{N}$ & $83^{\circ} 12.000^{\prime} \mathrm{W}$ & MI ${ }^{4}$ \\
Detroit & DET & Urban & $42^{\circ} 18.250^{\prime} \mathrm{N}$ & $83^{\circ} 06.000^{\prime} \mathrm{W}$ & MI \\
Oak Park & OAK & Urban & $42^{\circ} 27.784^{\prime} \mathrm{N}$ & $83^{\circ} 10.998^{\prime} \mathrm{W}$ & MI \\
Warren & WAR & Urban & $42^{\circ} 30.800^{\prime} \mathrm{N}$ & $83^{\circ} 00.000^{\prime} \mathrm{W}$ & MI \\
\hline
\end{tabular}

${ }^{1} \mathrm{OME}$ - Ontario Ministry of the Environment;

${ }^{2}$ EC - Environment Canada;

${ }^{3}$ IADN - Integrated Atmospheric Deposition Network;

${ }^{4}$ MI - Michigan State.

southwestern Ontario, Lake St. Clair, Detroit, and the northwestern quadrant of Lake Erie (Fig. 1), and model grid cells were grouped by different surface type (i.e., rural, lake, and urban).

Throughout the paper, Eastern Daylight Time (EDT) is used to present the data, which is one hour ahead of Eastern Standard Time (EST) and four hours behind Coordinated Universal Time (UTC).

\section{Results and discussion}

\subsection{Diurnal pattern of surface ozone}

To examine the diurnal behavior of ground-level ozone over the lakes as compared to land, 2-h averages of ozone and their hourly change rates were calculated for the Buoy (representing the lake), Pelee Island (representing lake influenced conditions), and the groups of 11 rural and six urban sites (Fig. 2). Ozone measurements over Lake Erie were also made by a monitor installed for BAQS-Met on the Leamington - Pelee Island ferry, but due to its routine movement it was not possible to compute relevant diurnal averages. The ferry measurements were therefore averaged by trip times (approximately $90 \mathrm{~min}$ for each trip), for four sailings that were scheduled for the same departure times on all weekdays (Fig. 2a). Thus only its over-lake measurements were combined for comparison with and to further support the buoy and Pelee Island measurements. Although differences in ozone concentrations between land and lake were suggested in previous studies, this is the first time a detailed diurnal pattern and change rate are available at high temporal resolution and compared between lake, rural and urban sites.

Figure 2 shows the averaged ozone diurnal pattern (2a) and change rates ( $2 b)$ measured at the different site types, as well as the average ozone diurnal pattern $(2 \mathrm{c})$ and change rates (2d) predicted for various surface types for the same period by the AURAMS model. The nighttime (00:00-06:00 EDT) ozone mixing ratio over the lake (buoy) is $\sim 5 \mathrm{ppbv}$ higher than the Pelee Island site, $\sim 15 \mathrm{ppbv}$ higher than the ruralsite average, and close to $25 \mathrm{ppbv}$ higher than the urban-site average. At 10:00 EDT, average ozone levels at the rural and urban sites match those of the buoy. Higher ozone concentrations over the lake at night are due to a lack of fresh NO emissions, particularly in comparison to urban areas, and lower deposition rates to water surface than land surfaces (e.g., Dye et al., 1995; Sillman et al., 1993). Examination of the morning (09:00 EDT) rate of increase in ozone at the buoy, shown in Fig. 2b, indicates that it is slower over water than over land (e.g., 1.5 vs. $3.4,5.8$, and $7.5 \mathrm{ppbv} \mathrm{h}^{-1}$, for the buoy, Pelee Island, rural, and urban sites, respectively). These differences are due to greater vertical mixing over land which quickly replenishes the ozone at the surface in the morning, particularly over the urban areas where ozone experiences 

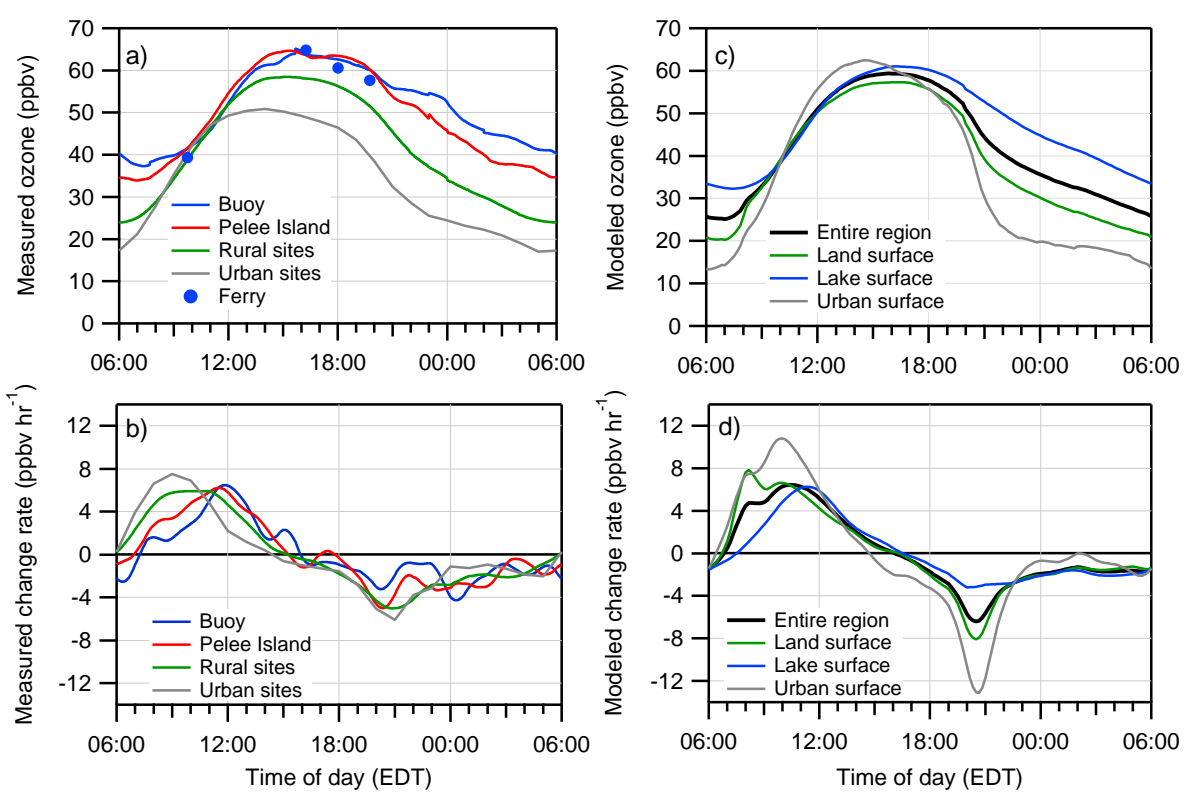

Fig. 2. (a) 2-h running averages of surface ozone for the Buoy, Pelee Island, rural-site composite, urban-site composite, and the average of ferry measurements for trips scheduled on all weekdays; (b) running change rate between two consecutive hours of the measured data; (c) AURAMS diurnal averages at surface level over the 2.5-km grid sub-domain in Fig. 1 grouped by lakes, land and urban areas; (d) running change rates between two consecutive hours of the model data.

the greatest depletion at night. This behavior suggests that the nighttime differences between lake and land are limited to a shallow layer above the surface since within a few hours after sunrise mixing from aloft results in a minimum in spatial variability in surface ozone from 10:00-11:00 EDT.

Previous studies have shown that the break up of the surface inversion and vertical mixing with the ozone residual layer aloft has a significant impact on morning build up of ground-level ozone, whereas photochemical production processes augment surface ozone levels later in the day (Zhang and Rao, 1999). Zhang and Rao (1999) found comparable summer mean ozone build-up rates at a rural site, with the highest rates $\left(\sim 6.5 \mathrm{ppbv} \mathrm{h}^{-1}\right)$ at 10:00 EDT, compared to $10 \mathrm{ppbv} \mathrm{h}^{-1}$ at 11:00 EDT at an urban site in New York City. Kleinman et al. (2002) used a chemical box model to estimate ozone build-up rates at five large cities in the United States. The authors found the highest rates of $11.3 \mathrm{ppbv} \mathrm{h}^{-1}$ in Philadelphia, PA and Houston TX, compared to 6, 4.3, and $3.5 \mathrm{ppbv} \mathrm{h}^{-1}$ in Nashville, TN, New York City, NY, and Phoenix, AZ, respectively. In this study over southwestern Ontario, measured rates of change of ozone mixing ratio at the urban sites (Fig. 2b) are between $8 \mathrm{ppbvh}^{-1}$ (at 09:00 EDT) and $-6 \mathrm{ppbvh}^{-1}$ (at 21:00 EDT).

To compare the measured diurnal cycles of ozone to those predicted by AURAMS, an analysis sub-domain of the 2.5$\mathrm{km}$ model grid was selected over the study region (Fig. 1). The AURAMS mean ozone diurnal pattern for the lakes versus land surfaces in the region (Fig. 2c, d) is similar to the measurements, with a $\sim 15$ ppbv difference at night and build-up rates of 2.7 and $6 \mathrm{ppbv} \mathrm{h}^{-1}$ over lake and land surfaces, respectively, at 09:00 EDT. Urban areas (i.e., mainly Detroit) over the modeled region show a higher build-up rate of $10.8 \mathrm{ppbvh}^{-1}$ in the morning (10:00 EDT) compared to the maximum rate of $7.5 \mathrm{ppbvh}^{-1}$ measured at the urban sites an hour earlier, as well as faster loss rates at night $\left(-13 \mathrm{ppbvh}^{-1}\right.$ at 20:30EDT) compared to measurements $\left(-6 \mathrm{ppbvh}^{-1}\right.$ at 21:00 EDT). These differences might be due, at least in part, to the six urban sites being located at or close to the city center, which are thus more influenced by traffic $\mathrm{NO}_{\mathrm{x}}$ emissions compared to the part of the model domain that is assigned to the "urban" group (cf. Fig. 1).

From 23:00 to 06:00 EDT Fig. 2b shows a general trend of decreasing measured ozone loss rates. In contrast, the model predicts an almost constant loss rate with a magnitude of about $2 \mathrm{ppbvh}^{-1}$. The result of these differences in nighttime change rates is lower predicted ozone mixing ratios in the morning (06:00 EDT) compared to measurements. These lower model values at sunrise are then compensated by higher predicted versus measured change rates in the morning, particularly over rural ( 8 vs. $6 \mathrm{ppbv} \mathrm{h}^{-1}$, respectively) and urban (11 vs. $8 \mathrm{ppbvh}^{-1}$, respectively) areas. As a result, the predicted daily maxima in the afternoon are higher than measured for urban areas (63 vs. 50 ppbv, respectively), but are in good agreement for rural areas $(\sim 58 \mathrm{ppbv})$.

Given the limited ability to obtain systematic threedimensional measurements, particularly over the lakes, and after showing reasonable agreement between measured and predicted average ozone levels near the surface in the study 

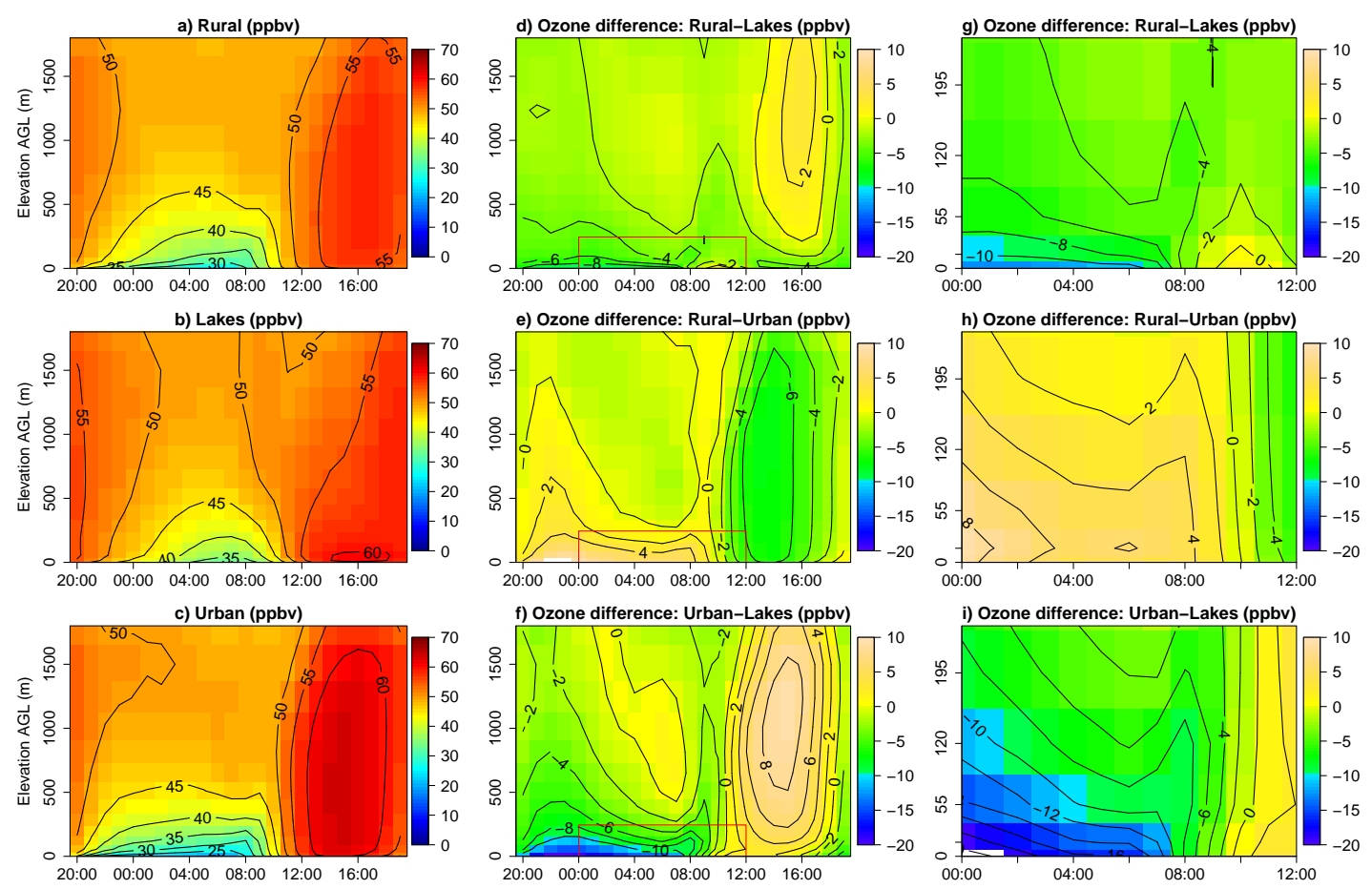

Fig. 3. Mean AURAMS model output showing time-height cross-sections for the sub-domain shown in Fig. 2, sorted by surface type: (a) rural; (b) lake; and (c) urban. Differences are shown between (d) rural and lake, (e) rural and urban, and (f) urban and lake surface types, with the red frames in the middle panels marking a higher-resolution cross-section for midnight-noon up to $240 \mathrm{~m}$ a.g.l. shown in panels (g), (h) and (i), respectively.

region in Fig. 2, the AURAMS output was examined to gain more insight into the vertical structure of ozone over the different surface types of rural, lakes and urban and to examine the suggestion that higher ozone levels over the lakes are limited to a shallow layer above the surface. Time-height cross sections extracted from the AURAMS mean hourly ozone fields for the buoy operational period (26 June-10 July), averaged further over the three surface types in the sub-domain are displayed in Fig. 3a-c. While overall relatively small differences are predicted throughout much of the vertical domain between the rural and lake surface types (Fig. 3a and $\mathrm{b}$, respectively), not surprisingly, the model produces lower ozone levels over the urban areas within about $200 \mathrm{~m}$ of the surface at night. In contrast, according to the model there are considerably higher levels within the lower $1500 \mathrm{~m}$ over the urban areas during the day (Fig. 3c).

Quantitative model estimates of the differences in the vertical structure of ozone between different surface types is shown in Fig. 3d-f, together with a closer examination of the lowest vertical levels (outlined with the red frames in Fig. 3d-f) shown in Fig. 3g-i. Confirming the interpretation of Fig. 2 above that the significant land-lake differences are limited to a shallow layer, Fig. 3d shows small differences (less than \pm 2 ppbv) in ozone levels over land vs. lake at the 200-1500 m levels in the early morning. Near the surface, however, differences are as high as $10-12 \mathrm{ppbv}$, but rapidly decrease to $4 \mathrm{ppbv}$ at $100 \mathrm{~m}$ (Fig. $3 \mathrm{~g}$ ). A detailed case study presented in Sect. 3.3 presents observations confirming this vertical structure and further detailing its impact on observed surface ozone. The largest contrast in the time-height cross sections is between the urban and lake surface types (Fig. 3f and i) near the surface at night (21:00-04:00), with the urban area being 14-20 ppbv lower than the lakes, in good agreement with observations shown in Fig. 2a, of about 25 ppbv difference between the buoy and urban sites at night. These nighttime differences are the result of two loss mechanisms near the surface that act at different intensities over land and over the water. First, greater $\mathrm{NO}_{\mathrm{x}}$ emissions over land (and over urban areas in particular) result in stronger ozone titration. Second, ozone has higher deposition velocities over land than over water. Adding to these mechanisms is the increased vertical stability over land due to radiative cooling of the surface that prevents vertical exchange and ozone replenishment from aloft.

\subsection{Spatial pattern of mean ozone}

The scarcity of continuous (in time and space) air pollution observations over the Great Lakes generally reduces the examination of their spatial distribution to short term field campaigns where multiple monitors are used around the lakes (e.g., Fast and Heilman, 2005), and/or from aircraft 
measurements are taken above the region (e.g., Hastie et al., 1999). In an attempt to bridge this gap and examine the spatial distribution of ozone over the study region, ozone mixing ratios from AURAMS for the entire 23-day BAQS-Met intensive observing campaign (20 June-10 July) were calculated. The spatial distributions of mean surface ozone mixing ratios for different times of day are shown in Fig. 4a. Modeled surface ozone mixing ratios are higher over the lakes as compared to their surroundings at all times of day (Fig. 4a1), but the difference is more pronounced at night with 10-15 ppbv difference between 21:00 and 06:00 EDT. This result is consistent with the actual measurements shown in Fig. 2a. However, the output from AURAMS indicates that ozone levels are not homogeneous over Lake Erie. This difference is most pronounced over the south-central part of Lake Erie (between Cleveland and Wheatley), where during the study period daily mean ozone levels reached a high of about $50 \mathrm{ppbv}$, compared to $41 \mathrm{ppbv}$ in southwestern Ontario. Note that particularly low ozone mixing ratios of 20-30 ppbv are predicted over the urban regions of Cleveland and Detroit, where emission levels are typically higher. It should also be noted that mean ozone mixing ratios over Lake Huron are lower than over Lake Erie. With the southwestern end of Lake Erie being ringed by the urban centers of Detroit, Toledo, and Cleveland (Fig. 1), this suggests that proximity to pollution emission sources is also an important factor. Fast and Heilman (2005) presented a similar finding for Lakes Erie and Huron in their modeling results.

Figure 4 also shows a vertical cross section between the surface and $3000 \mathrm{ma.g.l}$. of ozone (4b) and vertical wind (4c) along a transect across Lake St. Clair and Lake Erie, marked A-F in Fig. 4. The simulated mean ozone cross section shows a reservoir layer persisting after 21:00 EDT (Fig. 4b5), centered between 600 and $1000 \mathrm{~m}$ a.g.l., over Lake Erie and Cleveland. At the start of the overnight period (i.e., 00:00 EDT) the model suggests that higher ozone levels over Lake Erie are not limited to the lowest layers, but extend to about $1500 \mathrm{~m}$ a.g.l. By early morning (06:00 EDT) the modeled differences over land and over the lakes are much reduced and are limited to a shallow layer of less than $200 \mathrm{~m}$ a.g.l. In contrast, above about $500 \mathrm{~m}$ at this time the horizontal variation in ozone is small, with no apparent lakerelated features. The main differences in the early morning are over the large emission areas (Cleveland and west of Lake St. Clair) due to ozone titration by NO that is emitted into a shallow nocturnal surface layer.

After noon, when photochemical production is peaking, the modeled higher ozone over the lake $(60-70 \mathrm{ppbv}$, $\sim 10$ ppbv higher than over land, Fig. $4 b 4$ ) is limited to a shallower layer of about $100 \mathrm{~m}$ over Lake Erie. This is most evident over the US side of the lake, while on the Canadian side, ozone mixing ratios are lower (50-60 ppbv). This pattern is likely related to the assumed spatial distribution in emissions over the lake, where emissions on the US side are spread over the southern part of the lake while emissions on the Canadian side are allocated along the main shipping lane (see Makar et al., 2010b). At the same time, over Lake St. Clair the predicted high ozone levels of about $70 \mathrm{ppbv}$ extend up to $1500 \mathrm{~m}$ a.g.l. following the vertical extent of the coupled lake and urban circulation (Fig. 4c4). In the evening (21:00EDT) while ground-level ozone is reduced over land, it is 10-15 ppbv higher over Lake Erie, up to about $2000 \mathrm{~m}$ a.g.l. This difference is noticeable through the night and until early morning in the model output and is due to differences in the rate of surface deposition of ozone between land and water, the increased impact of NO titration of ozone after sunset over the land, and the decrease in ozone vertical exchange over land at night, as mentioned earlier.

Predicted high ozone levels are also noticeable near the surface during the day over the larger metropolitan areas of Detroit and Cleveland (Fig. 4a4), with values going from $35 \mathrm{ppbv}$ at the downtown areas (e.g., point $\mathrm{E}$ at the cross section in Fig. 4a4) to above 60 ppbv in the cities' outskirts. Unlike the high ozone predicted close to the surface of Lake Erie mentioned earlier, the high values over land extend up to about $1500 \mathrm{~m}$ a.g.l. (Fig. 4b4), corresponding to the vertical extent of the modeled breeze circulation cell, with rising air over land and descending over the lakes (Fig. 4c4). However, the high values over the lake are more widespread compared to the cities, particularly over the southwestern and central parts of Lake Erie, though emission sources over the water are not high.

It is interesting to note that during the night, low ozone mixing ratios predicted over Detroit extend to hundreds of meters above the ground (at 00:00EDT over point B in Fig. 4b2), while over Cleveland the titrated layer is shallower. This difference in the vertical extent of ozone titration could be explained in part by the vertical motion produced by the model over Detroit and over the adjacent part of Lake St. Clair at this time (over point B in Fig. 4c2). However, similar vertical flow is also predicted over Cleveland (Fig. 4c2 over point $\mathrm{E}$ ), without a similar effect on ozone above the surface. Additional measurements are needed to be able to determine the extent to which these features and city-to-city differences occur and their implications on the local air quality.

\subsection{Case study: 6-7 July 2007}

The analyses in the two previous subsections have examined the average temporal and spatial patterns of ozone in the study area for the BAQS-Met intensive observing period. In order to fully understand the complex influence of local terrain-driven circulations in this area, however, it is necessary to consider a day-specific case study. Based on a review of the BAQS-Met air-quality and meteorological measurement data, the 6-7 July period was identified as being an interesting example of the impact of local circulations associated with lake and land breezes on the time evolution and spatial distribution of ozone and other pollutants. The following paragraphs describe this period focusing on 

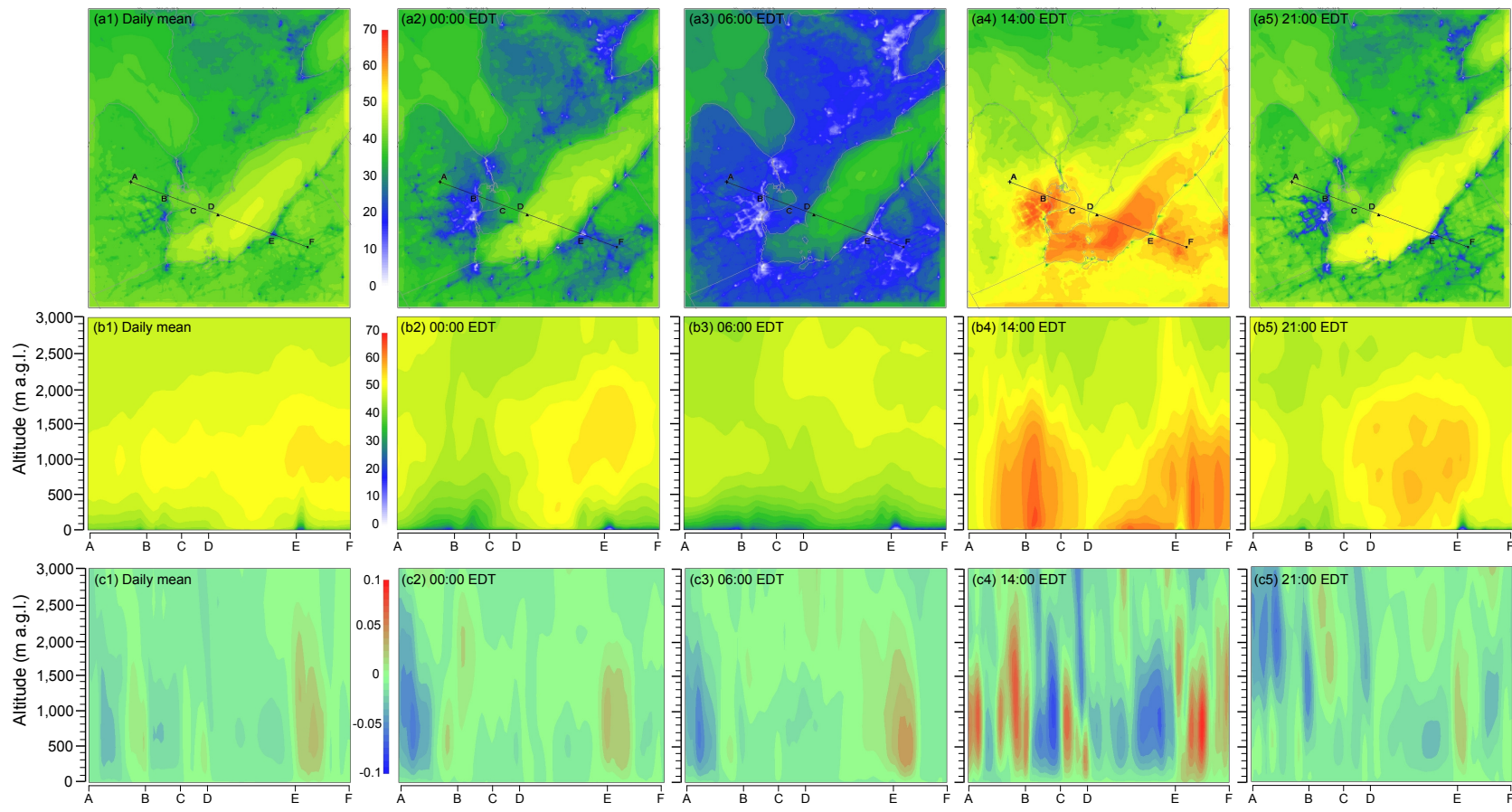

Fig. 4. Mean AURAMS model output showing (a) mean ground-level ozone, (b) mean ozone cross sections (ppbv), and (c) mean vertical velocity $\left(\mathrm{m} \mathrm{s}^{-1}\right)$ for all $24 \mathrm{~h}(\mathrm{a} 1, \mathrm{~b} 1$ and $\mathrm{c} 1)$ and selected times (00:00, 06:00, 14:00 and 21:00 EDT, a2-5, b2-5 and c2-5, respectively), calculated for the entire 23 days of the intensive campaign (18 June-10 July 2007). Cross sections are along transect A-F marked in (a), with contour intervals of $2 \mathrm{ppbv}$ for ozone and $0.01 \mathrm{~m} \mathrm{~s}^{-1}$ for vertical velocity.

conditions at the Harrow supersite, which is located $30 \mathrm{~km}$ southeast of the Detroit-Windsor urban complex (see Fig. 1). The Harrow area is affected by both Lake Erie and Lake St. Clair, as well as Detroit-Windsor. Measurements are also presented from additional surface sites, the Twin-Otter aircraft, and the Ridgetown tethersonde to obtain a more complete understanding of this case.

\subsubsection{Meteorology}

A high-pressure system approached the BAQS-Met study area from the west on 6 July, and passed south of the study region from SW to $\mathrm{S}$ on the $7 \mathrm{th}$. The ridge passage caused the light to moderate synoptic flow to shift from northwesterly on 6 July to westerly on 7 July in the morning. In addition, as shown in Fig. 5, superimposed on these synoptic features during this period were lake-induced winds and their associated sequence of mesoscale lake-breeze fronts. The positions of these fronts, which were determined for every hour of each day during BAQS-Met (Sills et al., 2010), were based upon multiple information sources including the meso-network, routine meteorological observation stations, and satellite and radar images.
The meso-analysis shown in Fig. 5a for 6 July 12:00 EDT suggests that a portion of the Lake Erie lake-breeze front (marked A and A1 in Fig. 5a) had just formed on the northwestern and western shores and was moving inland and northward south of Harrow. By 20:00 EDT (Fig. 5b) this lake-breeze front had passed over Harrow, reached the south shore of Lake St. Clair and stretched from Windsor to the southeast corner of Lake St. Clair. At this time a large part of extreme southwestern Ontario was experiencing southerly winds under an air mass that originated over Lake Erie, while northerly winds were prevalent over the reminder of the domain. The lake-breeze flow was moderately deformed by the synoptic winds so that lake-breeze fronts did not form on the downwind side (south shores) of the lakes (Sills et al., 2010). At 20:00 EDT on 6 July, the portion of the Lake Erie lake-breeze front that stretched from Windsor and to the south (marked A2 in Fig. 5b), was retreating eastward towards Harrow as the synoptic flow had swung around from northwesterly to westerly. A few hours later at 00:00 EDT on 7 July, a third lake-breeze front had almost reached Harrow from the northeast, this time generated earlier in the day at the southern end of Lake Huron (marked B in Fig. 5b and c).

Thus, during this period of less than a day, the detailed analysis of the meteorological conditions, enabled by deployment of the meso-network, revealed that air was transported to SW Ontario first from the northwest, then the south, 


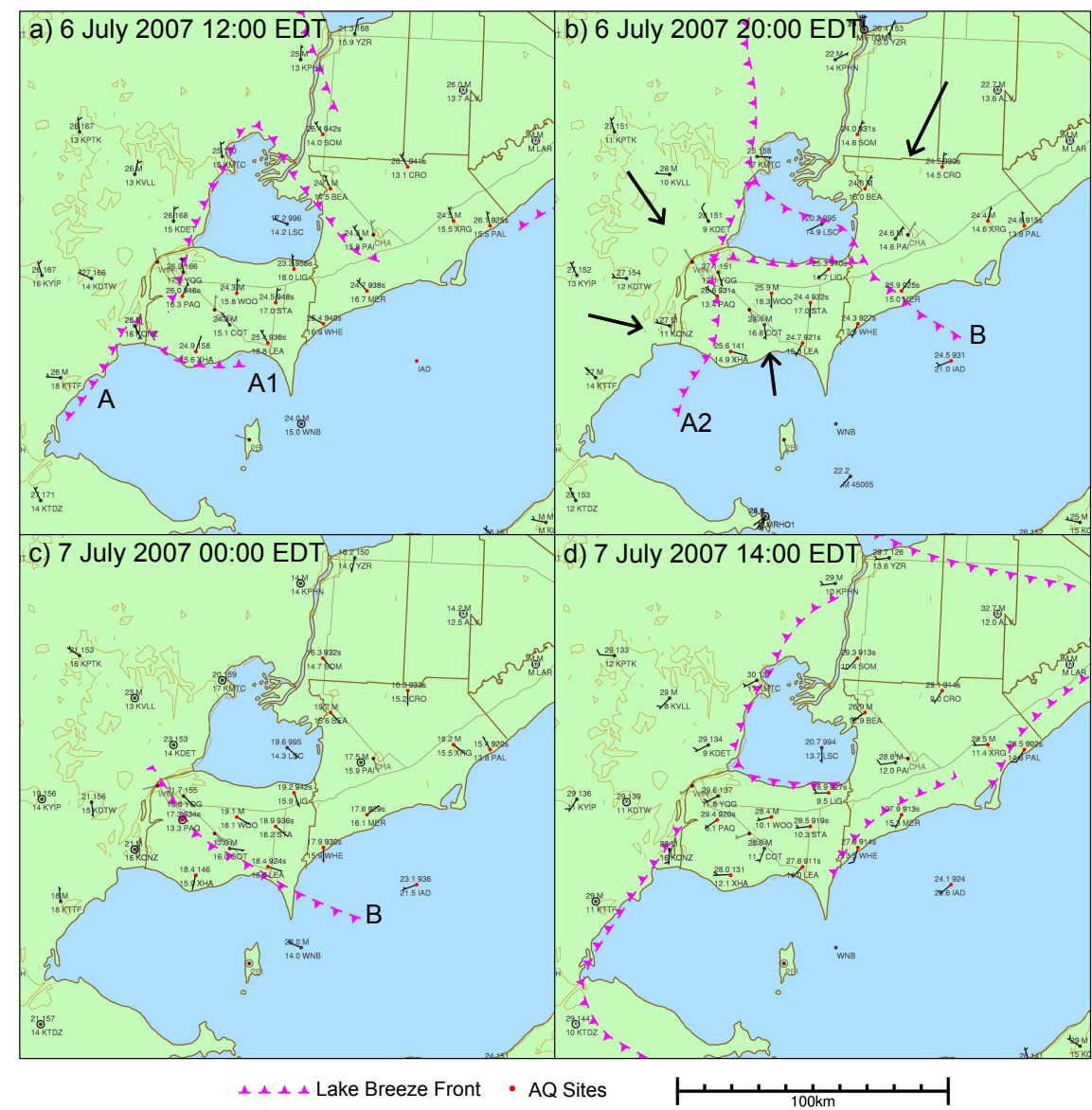

Fig. 5. Breeze-front locations on 6 July at (a) 12:00 EDT and (b) 20:00 EDT, and 7 July at (c) 00:00 EDT and (d) 14:00 EDT.

then the west, and then the northeast, as can also be seen in the wind measurements at the Harrow site (Fig. 6a). In addition, this analysis showed that size and location of the land area impacted by the "Lake Erie influenced air" changed continuously during the day and both Lakes St. Clair and Huron played a role in the mesoscale patterns as they evolved. These relatively dramatic meteorological changes provided a unique opportunity to examine in detail how these large lakes influence ozone and other air pollutants. Insights gained through such analyses provide additional measures for evaluating the capabilities of the high-resolution GEM and AURAMS models and for better assessing the true nature of the higher ozone occurring over and near the lakes. The discussion below will thus focus on how the chemical characteristics of the air masses changed with the lake-breeze-front transitions described above and in Sills et al. (2010).

\subsubsection{Air pollution}

Figure 6 shows concurrent time series from the Harrow supersite of wind speed and direction (Fig. 6a), $\mathrm{O}_{3}, \mathrm{SO}_{2}$, and $\mathrm{CO}$ mixing ratios (Fig. 6b), nitrogen oxides (NO, $\mathrm{NO}_{2}, \mathrm{NO}_{\mathrm{z}}$ and $\mathrm{NO}_{\mathrm{y}}$ ) and the toluene-to-benzene ratio (TBR, Fig. 6c) for 6-7 July. Also shown is $\mathrm{O}_{3}$ at three BAQS-Met sites east of Harrow (Wheatley, Leamington, and the Lake Erie buoy, Fig. 6d; see Fig. 1 for locations) for 6-7 July. As $\mathrm{NO}_{2}$ measurements from the supersite were not available for the morning of 6 July, measurements taken by the co-located instrument operated by the Ontario Ministry of Environment (OME) are presented in Fig. 6. Toluene and benzene measurements from the PTR-MS were used as one measure of the photochemical age of the air masses affecting the site (Roberts et al., 1984). Since both species are emitted from anthropogenic sources (mostly vehicle exhaust), and toluene is approximately four times more reactive with $\mathrm{OH}$ radicals, the lower the toluene/benzene ratio the more aged the air mass is. A ratio of about 4 indicates a freshly emitted air mass, while a ratio of about 1 marks an air mass emitted approximately 1-2 days earlier (Vlasenko et al., 2009). Below is a description of the different air masses identified during the $40 \mathrm{~h}$ period of 6 July 08:00 EDT to 8 July 00:00 EDT of the case study. For better clarity, certain time periods are marked in Fig. 6 in numbers (1-11) and referenced in the following text as different stages. 


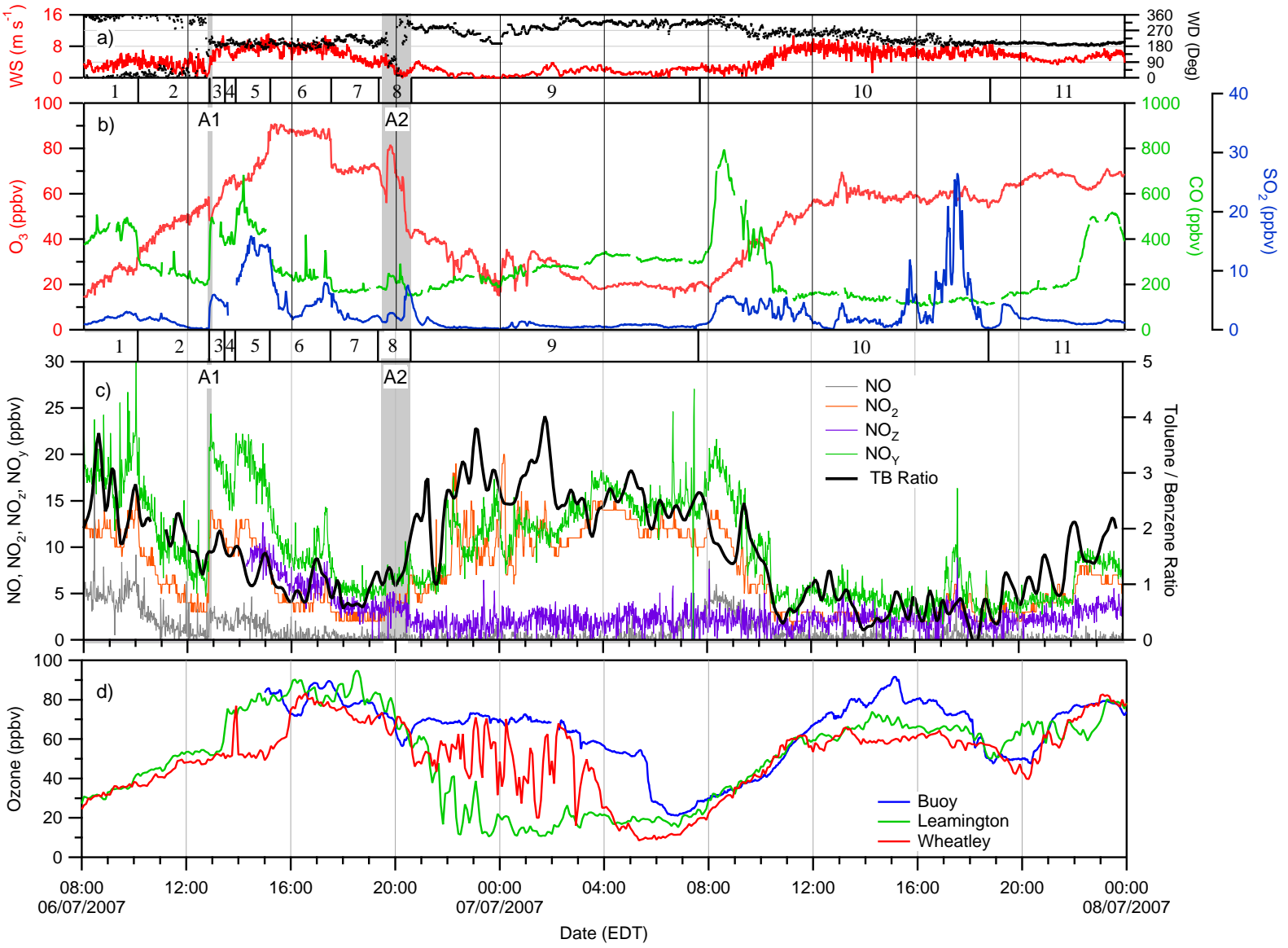

Fig. 6. Measurements from 6-7 July including: (a) wind speed and direction at Harrow; (b) $\mathrm{O}_{3}, \mathrm{CO}$ and $\mathrm{SO}_{2}$ mixing ratios at Harrow; (c) $\mathrm{NO}, \mathrm{NO}_{2}, \mathrm{NO}_{\mathrm{z}}$ and $\mathrm{NO}_{\mathrm{y}}$, as well as toluene-to-benzene ratio (TBR) at Harrow; and (d) $\mathrm{O}_{3}$ at three additional sites (Wheatley, Leamington, and the Lake Erie buoy). Thick gray vertical lines mark the times of the first two lake-breeze frontal passages at Harrow, marked A1 and A2. Numbering (1-11) refers to the different stages detailed in the text.

Stage 1 (08:00-10:05 EDT): a NNW flow (Fig. 6a) brings relatively fresh pollution to Harrow in the early morning hours, with $\mathrm{CO}$ levels of $400 \mathrm{ppbv}, \mathrm{NO}$ of $5 \mathrm{ppbv}$ and $\mathrm{NO}_{\mathrm{y}}$ of $20 \mathrm{ppbv}$. The high TBR of almost 3 and a wind speed of about $3-5 \mathrm{~m} \mathrm{~s}^{-1}\left(11-18 \mathrm{~km} \mathrm{hr}^{-1}\right)$ from the NNW support the assumption that these are polluted air masses arriving in an almost direct route from the Detroit-Windsor area.

Stage 2 (10:05-12:50EDT): a sharp drop of about $200 \mathrm{ppbv}$ in $\mathrm{CO}$ mixing ratios at 10:00 EDT, along with significant changes in ozone, $\mathrm{SO}_{2}, \mathrm{NO}$ and $\mathrm{NO}_{\mathrm{y}}$ mark a different air mass. This air is more photochemically aged, as seen by the lower TBR of 2.3-1.5, and with the winds having a more easterly component (wind direction of $0-45^{\circ}$, Fig. 6a), suggests an air mass that followed a longer path from Detroit to the east (i.e., north of Harrow) in the morning and now arrives at Harrow from the north, allowing more time for photochemical activity. Increases in mixing height due to the surface heating at this time, would also contribute to the above mentioned decrease in primary pollutants. However, the decrease in TBR at that time (from 2.3 to 1.5 ), being a ra- tio between ambient levels of two species and therefore not sensitive to changes in mixing height, suggests this air mass had also undergone more photochemical processing.

Stage 3 (12:50-13:25 EDT): the Lake Erie lake-breeze front passing at Harrow at 12:50 EDT (marked A1 in Fig. 6 between Stages 2 and 3) causes an abrupt change in wind direction from northwesterly to southerly and an increase in wind speed from 5 to $7 \mathrm{~m} \mathrm{~s}^{-1}$. The frontal passage coincides with a sharp drop in ozone, a dramatic increase in $\mathrm{NO}_{\mathrm{y}}$ (from 7 to $21 \mathrm{ppbv}$ ), $\mathrm{NO}$ (from 1 to $3 \mathrm{ppbv}$ ), $\mathrm{NO}_{2}$ (from 3 to $13 \mathrm{ppbv}$ ), and the TBR rises, which are all indicative of a fresher air mass. Indeed Fig. $6 \mathrm{~b}$ shows that $\mathrm{CO}$ also experienced an abrupt jump, from 202 to $491 \mathrm{ppbv}$, and $\mathrm{SO}_{2}$ increased from 0.2 to $5.6 \mathrm{ppbv}$. During Stage 3 there is also a rapid recovery in the ozone mixing ratio after the drop. This is either due to a change in its build-up rate from $18 \mathrm{ppb} \mathrm{hr}^{-1}$ in Stage 2 to $25 \mathrm{ppb} \mathrm{hr}^{-1}$ as a result of the availability of precursors and/or spatial heterogeneity in this new air mass with "pools" of higher NO locally destroying ozone, which would have been the cause of the drop at the start of Stage 3. 
Stages 4 (13:25-13:50EDT) and 5 (13:50-15:10EDT): during the short time period labeled as Stage 4 the wind continues to blow from the south, ozone increases more slowly and there are small decreases in $\mathrm{CO}, \mathrm{NO}_{\mathrm{y}}, \mathrm{NO}_{2}$ and $\mathrm{NO}$. These variations, as well as the observations during Stage 5, tend to indicate that there was considerable spatial heterogeneity in the air mass behind the lake-breeze front. The peak in $\mathrm{SO}_{2}$ during Stage 5, which is about 10 ppbv higher than the peak in Stage 3, and the maximum CO mixing ratio near this time further suggest that this fresh air mass contained a complex, variable mixture of primary pollutants.

The second intrusion of relatively fresh emissions at Harrow starting Stage 5 is surprising given the apparent origin of the air over Lake Erie. The wind directions over the region during the morning hours, however, suggest that this air mass likely originated near Detroit-Windsor. With NNW winds in the early morning these urban/industrial emissions could have followed the Detroit River traveling to the area of Lake Erie south and west of Harrow. Then this "pool" of relatively fresh emissions would have been transported northward across Harrow (at 12:50 EDT) into extreme southwestern Ontario behind the advancing lake-breeze front. The amount of temporal variability in the pollutant levels after the frontal passage (Stages 3, 4 and 5), which were all associated with southerly wind off the lake, suggests that the pollutants were recently emitted and experienced limited horizontal and vertical mixing. Transport early in the morning from Detroit-Windsor and then accumulation in the stable air over the lake could have led to this scenario. It is interesting to note that, with the exception of $\mathrm{SO}_{2}$, pollutant levels observed in Stages 3 and 5 were similar. This raises the possibility that the air mass in Stage 4 was a short "interruption" to a larger air mass containing ample ozone precursors and hence experiencing relatively rapid ozone formation.

Stage 6 (15:10-17:30 EDT): a sharp increase of 9 ppbv in ozone mixing ratios in two minutes (from 78 to 87 between 15:04 and 15:06) that is followed by a drop in $\mathrm{CO}, \mathrm{SO}_{2}$ and $\mathrm{NO}_{y}$ mixing ratios a few minutes later marks another dramatic change of air mass. Ozone levels during this stage maintain an almost constant and high value (85-90 ppbv), indicating an air mass that has been fully processed. This is supported by the low $\mathrm{NO}(<1 \mathrm{ppbv})$, the large ratio of $\mathrm{NO}_{\mathrm{z}}$ to $\mathrm{NO}_{\mathrm{x}}$, and minimum values in the TBR of 0.8 .

Stage 7 (17:30-19:10EDT): a change in wind direction from S to SW (Fig. 6a) and a decrease in ozone from 90 to $70 \mathrm{ppbv}$ at 17:30 that coincides with changes in $\mathrm{CO}, \mathrm{SO}_{2}$, $\mathrm{NO}_{\mathrm{y}}, \mathrm{NO}_{\mathrm{z}}$ and $\mathrm{NO}_{2}$ (Fig. $6 \mathrm{~b}$ and c) mark another change in air mass. This air also maintains a near-constant ozone level for almost two hours that together with the low TBR and high $\mathrm{NO}_{\mathrm{z}} / \mathrm{NO}_{\mathrm{y}}$ indicates this air mass was also photochemically aged. However, its origin and history were clearly different than in Stage 6 given that less ozone had been produced. Figure $5 \mathrm{~b}$ shows that during the period of southerly flow over the region (Stages 3-7) the Lake Erie air mass moves northward to the south shore of Lake St. Clair. The meso-network station at Lighthouse Cove (LIG in Fig. 1) experienced its peak ozone at $\sim 20: 00$ EDT just after the front (A) passed over, thus confirming the existence of higher ozone in this air mass, which covered a distinct area of about $2000 \mathrm{~km}^{2}$ at 20:00 EDT.

Stage 8 (19:10-20:35 EDT): as the retreating Lake Erie lake-breeze front passes Harrow for the second time from west to east (marked A2 on Fig. 5b and on Fig. 6) there was a large drop in ozone of $40 \mathrm{ppbv}$ in 35 min (between 19:50-20:25 EDT, Fig. 6b). This is accompanied by changes in other species, as well as wind speed and direction, and is hypothesized to be the result of complex three-dimensional flows in this frontal zone. This complexity is further indicated by the dramatic oscillation in ozone, dropping first by about $10 \mathrm{ppbv}$, then rising by $25 \mathrm{ppbv}$, and then halving from 80 to $40 \mathrm{ppbv}$. A detailed description of the meteorological and pollutant changes across lake-breeze frontal zones in this region is given in Hayden et al. (2010), based on BAQS-Met measurements taken at multiple heights on board the Twin Otter aircraft.

Stage 9 (20:35-07:40EDT): after the front (A2) passes east of Harrow, a westerly synoptic flow develops over the SW Ontario region. Wind speeds during this overnight period are light to stagnant, but gradually push the air mass with maximum values in ozone, east and south back towards Lake Erie. A fresher air mass moves over Harrow, as indicated by the increasing TBR after 20:00 EDT, a decrease in $\mathrm{NO}_{\mathrm{z}}$ and an increase in $\mathrm{NO}_{2}$ from $5 \mathrm{ppbv}$ at 21:00 to $14 \mathrm{ppbv}$ at 04:00 EDT (Fig. 6c). The westerly winds in the first few hours after the frontal passage and the analysis of the local meteorology in Sect. 3.3.1 suggest the Detroit-Windsor region as the source for the pollution at this time.

The light wind flow pushes the ozone-rich air eastward, where it is marked by a $40 \mathrm{ppbv}$ drop in ozone mixing ratio at Leamington (LEA in Fig. 1) between 21:00-22:00 EDT. This is shown in Fig. 6d along with ozone levels over the lake measured by the buoy and at the Wheatley meso-network site located further east (marked ECO and WHE in Fig. 1, respectively). Throughout the evening there is also continued southwestward movement of a third lake-breeze front (Lake Huron front), which eventually affects the region. At 20:00 EDT this front (marked B on Fig. 5b) stretches from rural areas in Michigan north of Detroit, through Lake St. Clair and then towards Lake Erie. Eventually, it pushes southwestward and passes Leamington at about midnight with ozone levels dropping further and stabilizing at about $10-20$ ppbv. According to the ozone in Fig. $6 \mathrm{~b}$ this front appears to have passed over Harrow at around 04:00 EDT on 7 July.

The result of these two later lake-breeze frontal passages (A2 and B) is a reduction in ozone mixing ratios over land in southwestern Ontario. However, high mixing ratios remain over Lake Erie since the Lake Huron front does not penetrate far enough south. The difference between the two air masses is clearly seen by comparing Leamington ozone 


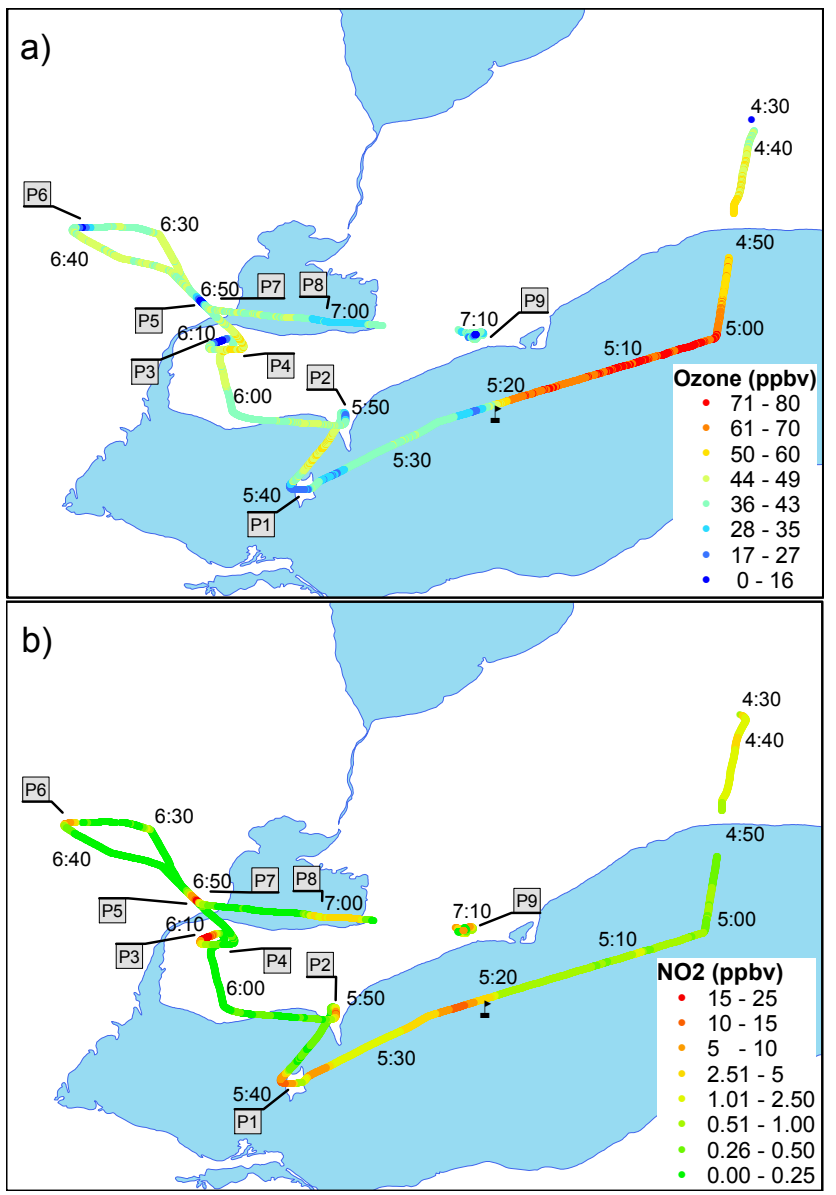

Fig. 7. Ozone (a) and $\mathrm{NO}_{2}$ (b) measured at early morning hours (04:30-07:20 EDT) of 7 July by the Twin Otter aircraft. Notation $\mathrm{P} 1-\mathrm{P} 9$ refers to vertical profiles shown in Fig. 8.

to the observations at the buoy (Fig. 6d). At 00:00 EDT (7 July) the mixing ratio was $70 \mathrm{ppbv}$ at the buoy and $20 \mathrm{ppbv}$ in Leamington, with the large difference between these two locations persisting until 05:30 EDT. The location of the edge of the ozone-rich air mass is evident at Wheatley, where ozone mixing ratios fluctuate during the night between the Leamington and Buoy levels. This boundary between the air masses was also observed by the Twin Otter aircraft as it flew WSW over Lake Erie during the early morning hours of 7 July. The aircraft passed approximately $5 \mathrm{~km} \mathrm{NE}$ of the buoy at $150 \mathrm{~m}$ a.g.l. at 05:20EDT (Fig. 7a) and detected a sudden steep drop in ozone from $70 \mathrm{ppbv}$ to $20 \mathrm{ppbv}$ and a simultaneous increase in $\mathrm{NO}_{2}$ (Fig. 7b). The vertical differences in ozone over land and over Lake Erie at this time are described in the following Sect. 3.3.3 and the oscillations in ozone observed at several sites are discussed in Sect. 3.3.4.

Stage 10 (07:40-18:50 EDT, 7 July): low wind speeds of $0-4 \mathrm{~m} \mathrm{~s}^{-1}$ (Fig. 6a) in the morning, an increase in NO from 2 to 4 ppbv (Fig. 6c), and sharp increases in $\mathrm{CO}$ from 300 to $800 \mathrm{ppbv}$ and in $\mathrm{SO}_{2}$ from almost 0 to $5 \mathrm{ppbv}$ (Fig. $6 \mathrm{~b}$ ) suggest a different and more polluted air mass arriving at Harrow. These mark the beginning of another stage, with a typical morning build-up of ozone from $19 \mathrm{ppbv}$ at 08:00 to $55 \mathrm{ppbv}$ at 13:00 (i.e., $7.2 \mathrm{ppbv} \mathrm{h}^{-1}$, comparable with the average $5.8 \mathrm{ppbv} \mathrm{h}^{-1}$ for 11 rural sites in the morning shown in Fig. 2). This stage continues through the day with a high of $60 \mathrm{ppbv}$ in ozone persisting through the evening. During this period wind speed increases to $6 \mathrm{~m} \mathrm{~s}^{-1}$ and gradually shifts from $\mathrm{NW}$ to $\mathrm{W}, \mathrm{SW}$, and southerly flow (Fig. 6a). $\mathrm{SO}_{2}$ peaks of 12 ppbv at 15:45 EDT and 27 ppbv at 17:35 EDT, both associated with high $\mathrm{NO}_{\mathrm{y}}$ and low $(<1)$ TBR, are observed during the afternoon southwesterly flow. These suggest more freshly emitted pollutants that, with the southwesterly flow, point to local to regional transport of polluted air crossing over Lake Erie, potentially related to a large power plant near the western shore of the lake.

Stage 11 (18:50-00:00EDT, July $\left.7^{\text {th }}\right)$ : uncharacteristically high ozone after sunset at Harrow (Fig. 6b) and other sites in the region (Fig. 6d) is observed at this stage. There was also a higher TBR ratio compared to the previous stage, reaching 2, and an increase in $\mathrm{CO}, \mathrm{NO}_{2}$ and $\mathrm{NO}_{\mathrm{y}}$ after 22:00 EDT. The regional spread of the high ozone, being measured at multiple sites in the study region (Fig. 6d), and the persistent and moderate southwesterly winds (Fig. 6a) suggest that a large regional airmass with elevated ozone was being transported from southwest of Lake Erie. At the same time, some more local sources were likely adding to this airmass, as evidenced by the higher TBR and primary pollutant levels. Ozone remained high across the region after sunset due to turbulent/mechanical mixing induced by moderate winds, which continued to bring the higher ozone aloft to the surface and tended to homogenize the levels throughout the region.

The detailed description above demonstrates the complexity of the factors controlling ozone levels in southwestern Ontario observed in a short period of $40 \mathrm{~h}$. Pollution sources affecting the region can be from long-range transport (Stage 11) or relatively local emissions (e.g., Detroit-Windsor) that are transported in complex pathways by land-lake breeze winds (e.g., Stages 6 and 7), while undergoing photochemical processing, and by larger-scale flows (e.g., Stage 9). Furthermore, the air arriving with the lake breeze is often heterogeneous in its composition and photochemical age, as demonstrated in Stages 3-7.

\subsubsection{Vertical structure}

Given the complexity described above in surface ozone for the case study, the vertical structure of ozone in the lower troposphere is examined in the following paragraphs. Measurements supporting the limited vertical extent of enhanced ozone levels over Lake Erie discussed in Sects. 3.1 and 3.2, are found in the early morning of 7 July. At this time vertical profiles of ozone were obtained by the aircraft (Fig. 8) and by tethersonde launches at Ridgetown (Fig. 9). A temperature 

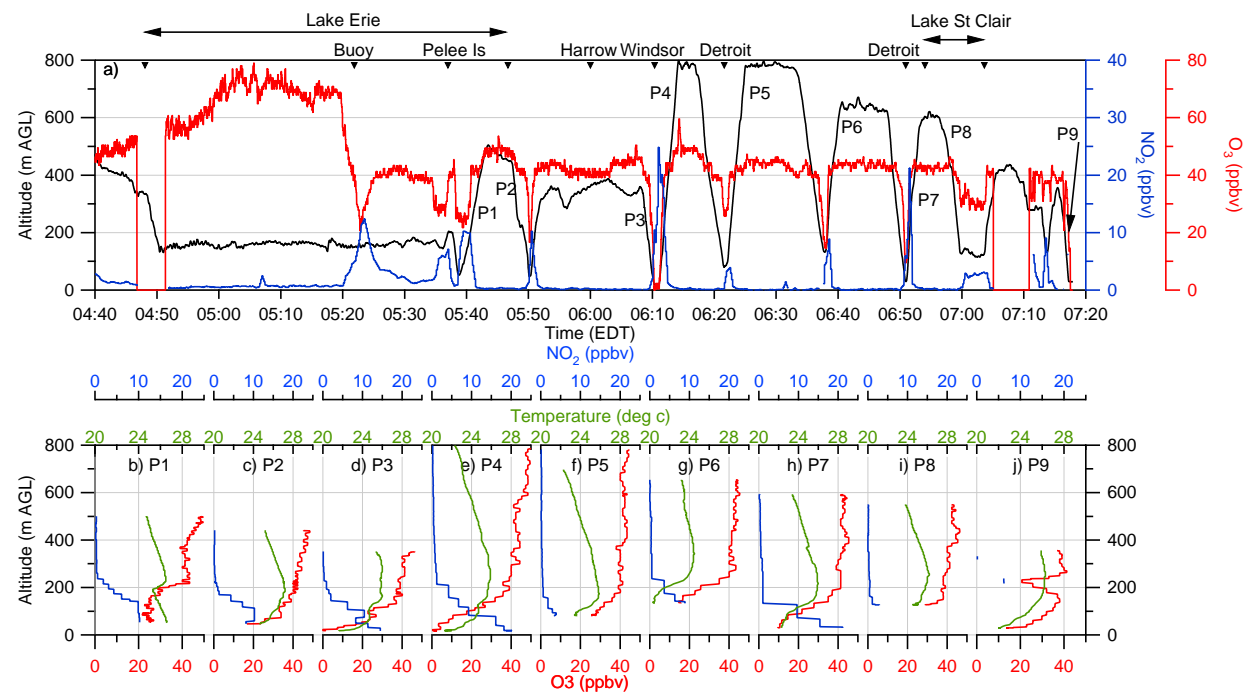

Fig. 8. (a) Twin Otter time series for 7 July showing $\mathrm{O}_{3}, \mathrm{NO}_{2}$, and elevation; (b-j) selected vertical profiles of $\mathrm{O}_{3}, \mathrm{NO}_{2}$, and temperature. Profile locations are indicated on Fig. 7.

profile taken by the aircraft over Lake Erie at 05:40 EDT ascending from Pelee Island (Fig. 8b and marked P1 in Figs. 7a and 8a; timing corresponds to Stage 9 described above) shows a thermal inversion layer between $200-235 \mathrm{~m}$ a.g.l. The inversion separates a low-ozone layer near the surface (about $25 \mathrm{ppbv}$ ) that is also $\mathrm{NO}_{2}$-rich (10 ppbv) from the regional ozone levels of $40-45$ ppbv observed above the inversion along with lower $\mathrm{NO}_{2}$ levels. Over land, however, the thermal inversion starts at the surface due to radiative cooling overnight (profiles P2-P7 and P9 in Figs. 7, 8c-h and j). This results in higher $\mathrm{NO}_{2}$ (e.g., 20 ppbv over Windsor in $\mathrm{P} 4$ and over Detroit in P7, Fig. 8e and h, respectively) and consequently much lower ozone levels near the ground (e.g., about 5 ppbv near Windsor, P4, Fig. 8e). However, ozone is rapidly increasing with height within the surface inversion layer of about $150 \mathrm{~m}$ a.g.l., and above that layer it is over $40 \mathrm{ppbv}$, the same as over the lake at this altitude.

Tethersonde launches at Ridgetown on the same morning support these findings and show a surface inversion up to about $100 \mathrm{~m}$ a.g.l. at 06:00 EDT (Fig. 9b), with ozone levels increasing from zero to $50 \mathrm{ppbv}$ with altitude, and stabilizing at $40 \mathrm{ppbv}$ above $300 \mathrm{~m}$. The air mass sampled by the early morning launches P1-P6 (Fig. 9b-g, respectively) is the same as the one described in Stage 9 at Harrow, dominated by a westerly large scale flow. Thus, the uniqueness of the conditions over the lake (i.e., higher ozone) is limited to a shallow surface layer $(<200 \mathrm{~m})$, while the reservoir of ozone aloft is similar across this larger region with no evidence of the land-lake difference.

Of special note is the difference in the ozone vertical profile below the inversion layer between the lake and land before sunrise. While ozone mixing ratios are almost constant over the lake in this layer (about 25 ppbv, Fig. 8b), over the adjacent land (Fig. 8c) the observed mixing ratios are much lower near the surface ( $17 \mathrm{ppbv}$ at $47 \mathrm{~m}$ ) but rapidly increase (34 ppbv at $73 \mathrm{~m}$ ) with altitude. These vertical changes result from the different thermal structure over the two surfaces during the early morning hours. The surface inversion over land suppresses any vertical mixing and allows much of the ozone near the ground to be titrated by nitrogen oxides emissions or be deposited to the surface.

Subsequent tethersonde launches in that morning show that ozone levels are rapidly increasing after sunrise at the lowest surface level from 0 to $16 \mathrm{ppbv}$ between 06:00 to 07:34 (Fig. 9b to e), while decreasing at the $50 \mathrm{~m}$ a.g.l. level from 33 to $20 \mathrm{ppbv}$. These changes correspond to changes in the temperature profile with a breakup of the surface inversion occurring between 06:51 and 07:34 EDT (marked P3 and $\mathrm{P} 4$ in Fig. 9d and e, respectively). More evidence of this process is found in the morning change rates in surface ozone at the monitoring sites over lake and over land. While differences of $\sim 10 \mathrm{ppbv}$ in surface ozone levels between lake (Buoy) and land (Wheatley) are observed in the early morning hours (07:00 EDT, Fig. 6d), ozone change rates in the morning are faster over land than over the lake, so that by 09:00 EDT both sites reach $35 \mathrm{ppbv}$ of ozone. The early morning change rate in surface ozone over land is thus shown to be the result of vertical mixing with an ozone-rich layer at a higher altitude.

An interesting feature observed at Ridgetown is a decrease in ozone mixing ratios in a shallow layer above the surface. This layer starts at $250 \mathrm{~m}$ a.g.l. (06:09 EDT) and descends to $78 \mathrm{~m}$ a.g.l. by $07: 32 \mathrm{EDT}$ (Fig. $9 \mathrm{~b}$ and e, respectively). A similar feature observed over the Chatham-Kent airport at $200 \mathrm{~m}$ a.g.l. by the Twin Otter at 07:16 EDT (Fig. 8j and marked P9 in Fig. 7a), and the NNW wind over the region 

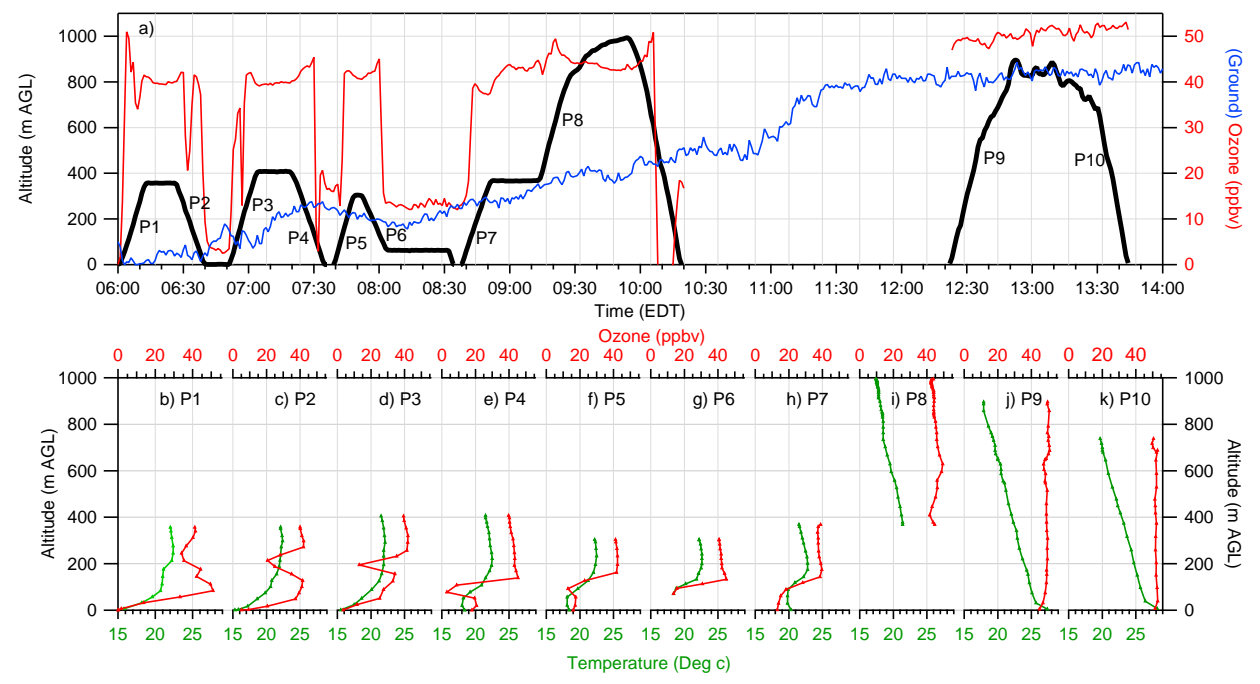

Fig. 9. (a) Time series for 7 July showing tethersonde elevation (black) and ozone mixing ratio (red) and ground-level ozone measured at the Ridgetown site (blue). (b-k) tethersonde vertical profiles of $\mathrm{O}_{3}$ (red) and temperature (green) at Ridgetown. Profiles are numbered from P1 to P10.

suggest the presence of a fan-shaped $\mathrm{NO}_{\mathrm{x}}$ plume, possibly from the Lambton power plant south of Sarnia, ON (Fig. 1). Cases of $\mathrm{NO}_{2}$ aloft over Ridgetown are discussed by Halla et al. (2010).

A second Twin Otter flight made later on 7 July from 13:30 to 16:20 EDT examined the vertical cross section over Lake St. Clair up to $2600 \mathrm{~m}$ a.g.l. A moderate westerly flow dominated the region in the late morning (also observed at Harrow, Fig. 6a), transporting ozone and its precursors from the Detroit region over Lake St. Clair. By noon a stationary Lake St. Clair lake-breeze front is established over the southern and western shores of the lake and stalls for several hours until evening (Fig. 5d), while the regional flow changes to WSW (Fig. 6a). A plan view of the flight (Fig. 10a) and a time series (Fig. 11a) show an increase in in ozone mixing ratios from about $55 \mathrm{ppbv}$ to $65 \mathrm{ppbv}$ as the aircraft crosses the shore at the southern side of the lake, both at $500 \mathrm{~m}$ and $700 \mathrm{~m}$ a.g.l. at 14:40 and 14:59 EDT, respectively. The stationary Lake St. Clair lake-breeze front located on the shore at that time marks the boundary between two air masses. On the northeastern side of the lake, high ozone values extend some $20 \mathrm{~km}$ from the lake at $300 \mathrm{~m}, 500 \mathrm{~m}$, and $740 \mathrm{~m}$ altitudes a.g.l. (Fig. 10b). At the $1400 \mathrm{~m}$ level, high ozone is more limited in its horizontal extent and does not reach beyond the lake. The vertical extent of the high ozone values reaches $1900 \mathrm{~m}$ a.g.l., where a subsidence inversion layer is encountered, and ozone mixing ratios decrease at a steady rate (Fig. 11). These measurements suggest the presence of a dome-shaped high ozone region over Lake St. Clair at noon, that is shifted and stretched at lower levels to the northeast, with peak values of about $85 \mathrm{ppbv}$ at the lake surface. Other model simulations (Makar et al., 2010b) examine the formation mechanism of this feature in detail: the coupling of emissions from Detroit, the city's heat island circulation with the Lake St. Clair subsidence flow, and possible recirculation of pollutants over Lake St. Clair.

\subsubsection{Nocturnal ozone oscillations}

Nighttime oscillations in ozone mixing ratios were observed at several monitoring sites during the BAQS-Met campaign. These were characterized by amplitudes of $20-40 \mathrm{ppbv}$ and time periods of $15-40 \mathrm{~min}$, changing from site to site and continuing for several hours. The oscillations occurred at multiple sites and different nights (e.g., 24-25 June, 29-30 June and 4-5 July), but had the highest amplitude and longest duration on the night of 6-7 July. Figure 12 shows meteorological measurements (wind speed and direction, temperature, dewpoint temperature and relative humidity) as well as ozone at four ground sites in SW Ontario where oscillations were observed on the night of 6-7 July (sites locations are indicated in Fig. 1): Bear Creek (mostly between 02:00-03:00 EDT, Fig. 12a); Lighthouse Cove (between 21:00-01:30EDT, Fig. 12b); Leamington (between 21:00-01:00 EDT, Fig. 12c); and Wheatley (between 21:0004:00 EDT, Fig. 12d). The oscillations occurred during periods with calm winds at the surface $\left(0-3 \mathrm{~m} \mathrm{~s}^{-1}\right.$, red line in top panels in Fig. 12) and are associated with oscillations in temperature and relative humidity (black and blue lines, respectively, in bottom panels of Fig. 12), so that peaks in ozone correspond to peaks in temperature and lows in relative humidity. Dewpoint temperature (shown in green in Fig. 12) shows a different behavior at different times and at different locations with respect to the oscillations in ozone and temperature. Looking at the Leamington site (Fig. 12c), dewpoint is correlated with temperature and ozone at some times 


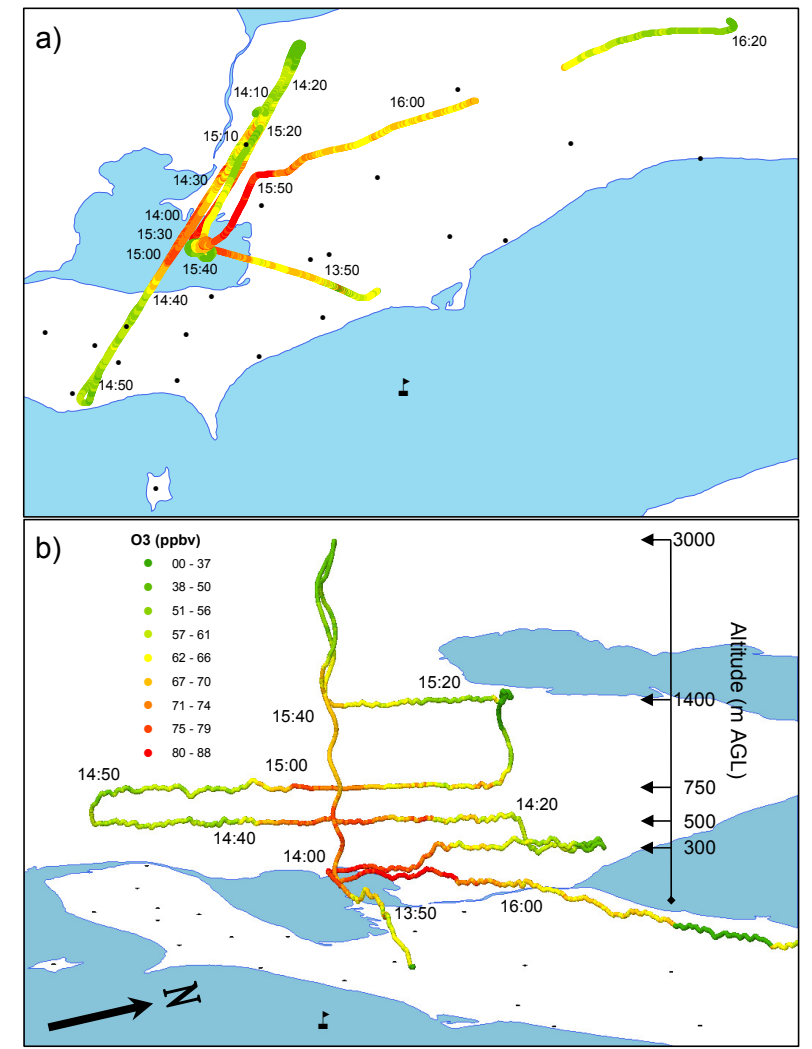

Fig. 10. (a) Plan view and (b) side view from southeast of the aircraft flight on 7 July 2007 between 13:40 and 16:20 EDT, with colors indicating ozone mixing ratios (ppbv). Times are related to the time series shown in Fig. 11.

(e.g., 23:15) and anti-correlated at other times (e.g., 03:0003:15). At the other sites where dewpoint was measured it shows no change corresponding to the change in temperature (e.g., Lighthouse Cove between 23:00 and 02:00) or very little change but good correlation (e.g., Wheatley between 01:00-04:00). Note also that Fig. 6 shows ozone traces for this same night at two other sites, Harrow and the Lake Erie Buoy, with some evidence of oscillations at Harrow.

Increases in nighttime ozone levels have been identified in other studies at different locations, and explained by nocturnal low-level jets (e.g., Corsmeier et al., 1997), intermittent turbulence (Salmond and McKendry, 2002), and stratospheric intrusions (e.g., Mavrakis et al., 2010). However, these studies observed either a secondary nighttime maximum or an abrupt increase in ozone mixing ratios, not oscillatory behavior. The difference in observations between the BAQS-Met study described here and previous studies could be the result of different physical mechanisms producing high nocturnal ozone, or in part simply due to the finer temporal resolution of the ozone measurements taken during BAQS-Met, of 1 min (e.g. at Bear Creek) and 5 min (at Leamington, Lighthouse Cove and Wheatley) and of $1 \mathrm{~min}$ for meteorological parameters in all sites. In spite of the strong amplitude of the observed oscillations (e.g., $40 \mathrm{ppbv}$ drop in $25 \mathrm{~min}$ at Wheatley), they would not necessarily appear in hourly averaged ozone data that is typically recorded by air quality monitoring networks because of the smaller time periods of $15-40 \mathrm{~min}$.

One possible explanation for the oscillations is intermittent turbulence causing a vertical mixing of air from the ozone-rich residual layer aloft with the nocturnal boundary layer near the surface. As discussed in the previous section, vertical stratification of ozone occurs after sunset over land with low ozone (due to NO titration and deposition) and cooler air near the surface and higher ozone and warmer air in a residual layer just above it. This vertical structure can be seen in the vertical profiles taken by the aircraft in the early morning over land between Leamington and Wheatley (Fig. 8c, location marked as P2 in Fig. 7), showing a surface inversion layer up to $200 \mathrm{~m}$ a.g.l. and by the tethersonde launch at Ridgetown at 06:00 EDT (Fig. 9b) showing a surface inversion layer up to $100 \mathrm{~m}$ a.g.l. Such a vertical structure is probably due to radiative cooling of the surface under the anti-cyclonic conditions on that night.

Given such a vertical stratification, turbulence and injection of air from aloft could then result in the observed oscillations at the surface. Indeed, ozone measurements of the aircraft over the lake at 05:00-05:20 EDT at about $180 \mathrm{~m}$ a.g.l. (Fig. 7a) show high mixing ratios of $60-80 \mathrm{ppbv}$, matching the values measured at Wheatley during the oscillations. Given the westerly synoptic flow during that night described in Stage 9 (see Sect. 3.3.2), it is likely that the same ozonerich air mass was present over SW Ontario at night, and was the source of the high ozone measured at the surface. Salmond and McKendry (2005) describe five possible causes for turbulence in the stable nocturnal boundary layer, including shear as a result of friction near the ground; low-level jets; mesoscale winds due to, e.g., land/sea breeze; breaking gravity waves; and density currents. While shear near the surface and the land/lake breeze are unlikely given the very low horizontal surface winds measured on that night, all other three causes could explain the observed oscillations.

Stronger winds in the residual layer aloft could cause a wind shear between the two layers, resulting in a nocturnal low level jets as described by Reitebuch et al. (2000) and Corsmeier et al. (1997). GEM/AURAMS model results support the low-level jet explanation, showing high wind speeds just above the surface on several occasions during that night. Figure 13 shows plan views at the surface (Fig. 13a, b) and cross sections of wind speeds above SW Ontario (Fig. 13c, d) at two times, 22:00 and 03:20 EDT. The model predicts high wind speeds just above the surface either as extensions of stronger winds above $1000 \mathrm{~m}$ a.g.l. at 22:00 EDT (Fig. 13c, marked $i$ and $j$ ) or isolated from the stronger winds aloft such as at 03:20 EDT in Fig. 13d (marked k, 1 and m). Strong gradients in wind speed from the surface to $100 \mathrm{~m}$ a.g.l. are predicted at these locations, with speeds increasing from $2 \mathrm{~m} \mathrm{~s}^{-1}$ 


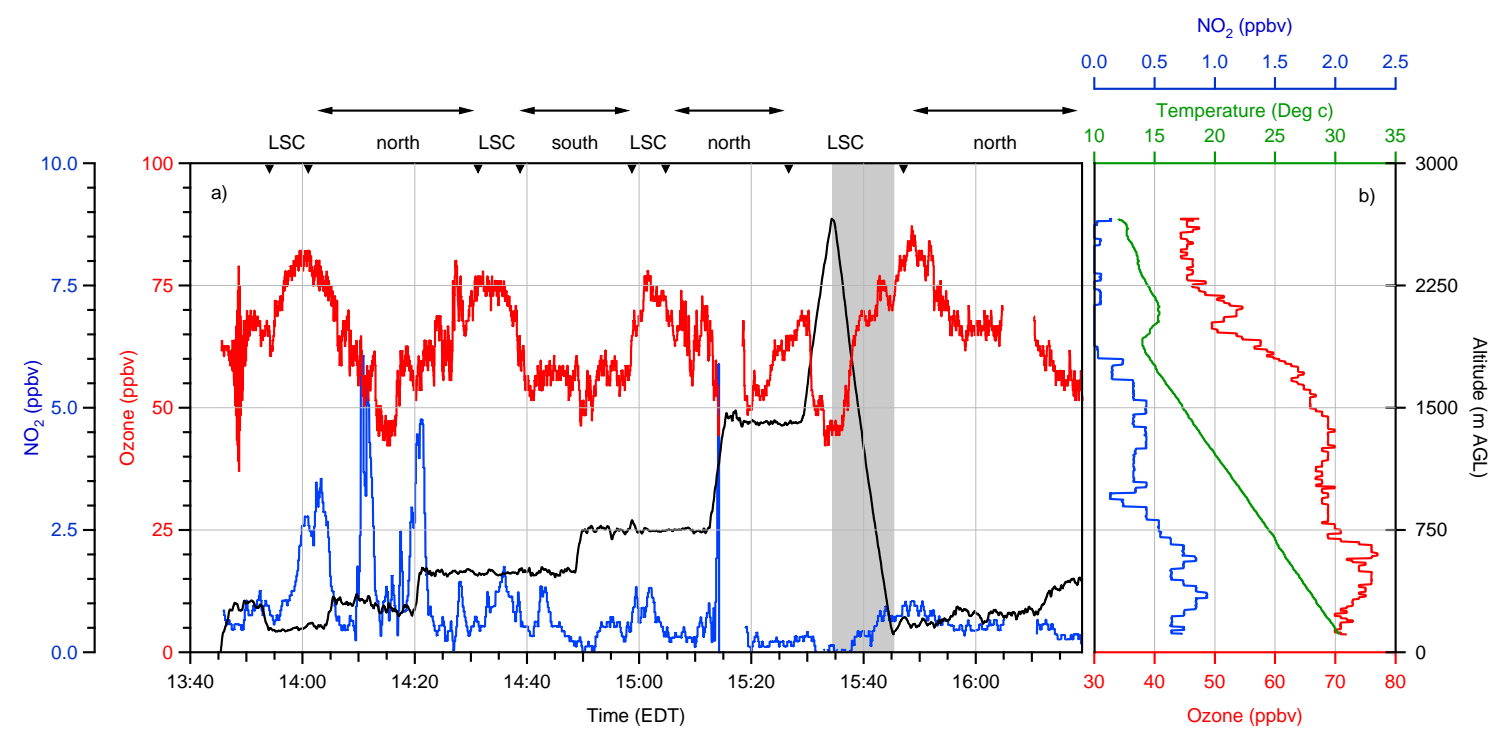

Fig. 11. (a) Twin Otter time series of $\mathrm{O}_{3}, \mathrm{NO}_{2}$, and elevation; (b) vertical profiles of $\mathrm{O}_{3}, \mathrm{NO}_{2}$, and temperature over Lake St. Clair. Profile period is indicated as shaded area. Top notation refers to periods when the aircraft is located over, to the north, or to the south of Lake St. Clair (LSC).

near the surface to $6 \mathrm{~m} \mathrm{~s}^{-1}$ (Fig. 13c, near i and j) and even $8 \mathrm{~m} \mathrm{~s}^{-1}$ (Fig. 13d, near k, 1 and m). Furthermore, the heterogeneity in the horizontal gradients of the wind speed predicted by the model near the surface (e.g., near point $D$ in Figs. 13a, b) and just above the surface at the same location (e.g., Fig. 13c, d at $200 \mathrm{~m}$ a.g.l.) would result in higher potential for the vertical mixing to occur over certain locations.

It is also possible that differential radiative cooling of the surface would cause parcels of warmer air near the surface to ascend and develop gravity waves, thus causing turbulence and forcing air from higher levels to reach the surface, where it is observed as warmer and more ozone-rich air. The caveats with this explanation are that the rising warm air is likely to be replaced laterally by cooler air and that the surface layer would have to be very shallow to allow air from aloft to reach the ground in such a mechanism.

Lastly, given the movements of the retreating Lake Erie breeze front and the advancing Lake Huron breeze front through the region on that night, as described in Sects. 3.3.1 and 3.3.2, it is possible that these fronts generate shearinduced instabilities ahead and behind them that might result in periodic turbulence. Such Kelvin-Helmholtz billows induced by the front's density current could be a possible mechanism that injects air from higher elevations to the surface, as described by Sun et al. (2002). However, as with the first explanation, this mechanism would also result in short bursts of stronger winds measured at the surface, which are not observed in the measurements, but conceivably the shear-induced vertical mixing could occur upwind of the station and then horizontal advection could transport the ozoneenriched air over the station. In fact, if a number of bil- lows overturned and collapsed, a number of near-surface horizontal "bands" of alternating ozone-rich and ozone-poor air could be created that could cause concentration oscillations at a fixed site if they were then advected over the site in succession.

Apart from intermittent turbulence, two other explanations can be suggested for this behavior. First, assuming that the oscillations are related to the Lake Huron breeze front described above in Stage 9, it is possible that this nighttime front has a similar motion to that noted by Drobinski et al. (2007), with oscillatory behavior in its advance, and a buildup of pollutants $\left(\mathrm{NO}_{\mathrm{x}}\right.$, resulting in ozone titration at night), just behind the front. However, the observations at SW Ontario occurred during the night, making it less likely for the lake-breeze front to propagate by this mechanism. But some apparent oscillations might in fact be step changes associated with a nighttime frontal passage, such as the drops in ozone at Lighthouse Cove (Fig. 12b) and Bear Creek (Fig. 12c) at about 21:15 EDT due to the passage of the Lake Huron breeze front. And second, given the similarity in ozone levels measured over Lake Erie at the buoy and ozone peaks at the proximate Wheatley site $(1.2 \mathrm{~km}$ from the lake), it is not unreasonable to assume lateral penetrations of ozone-rich lake air to the adjacent land. However, such penetrations would be expected to be accompanied by changing surface winds, which are very weak during the first part of the night at Wheatley although there are oscillations in wind direction from a southerly to a northerly direction and back (Fig. 12d, between 22:00-01:00 EDT). 

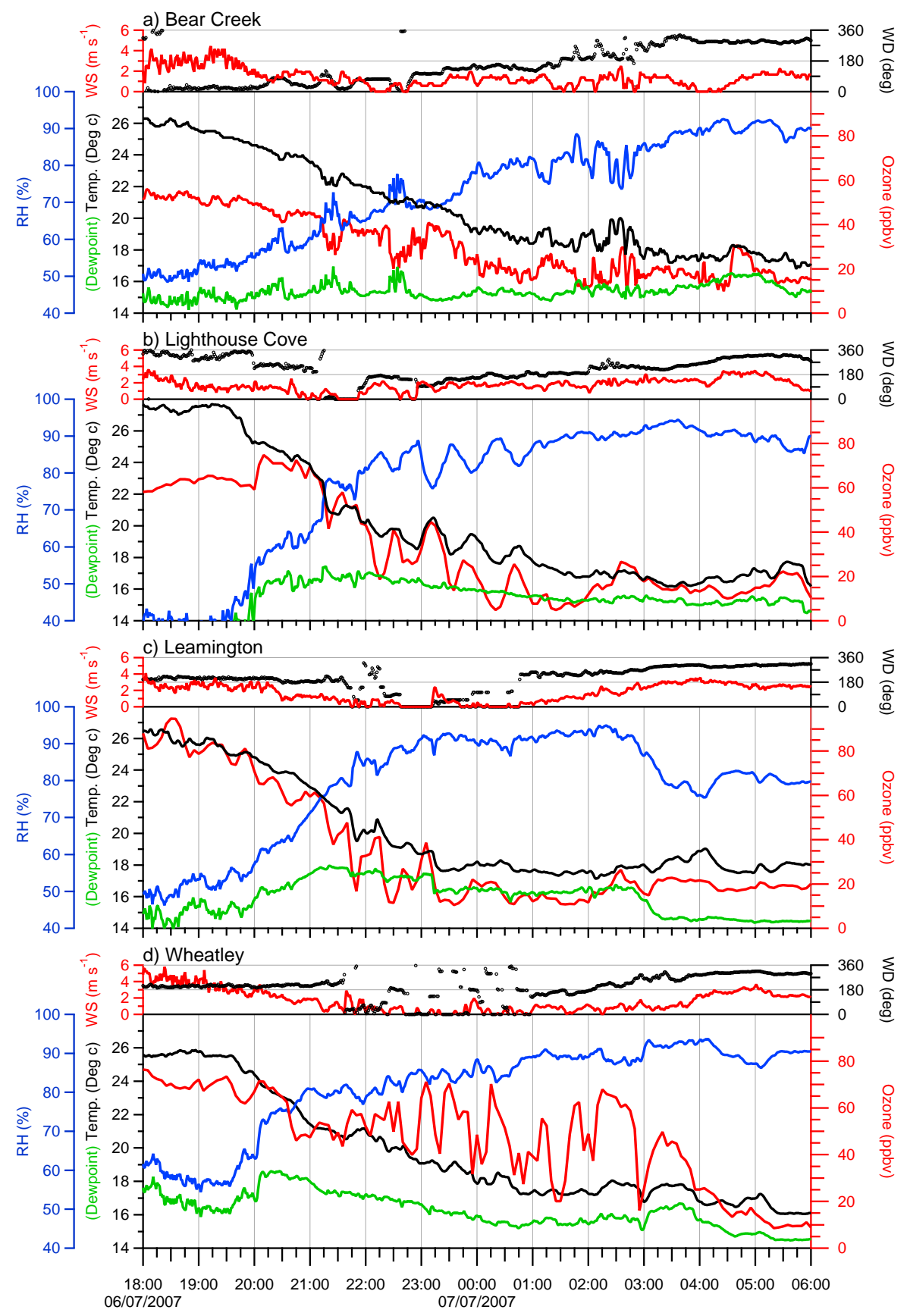

Fig. 12. Meteorological (wind speed (red) and direction (black), temperature (black), dewpoint temperature (green), and relative humidity (blue) ) and ozone (red) measurements during the night of 6-7 July, 2007 at four ground stations (a - Bear Creek, b - Lighthouse Cove, cLeamington and $\mathbf{d}$ - Wheatley).

If correct, the intermittent turbulence explanation also suggests heterogeneity in ozone levels in the residual layer, with $45 \mathrm{ppbv}$ at Lighthouse Cove, $40 \mathrm{ppbv}$ at Leamington, and $70 \mathrm{ppbv}$ at Wheatley (Fig. 12). However, as none of the above conceptual models given for the observed oscillations is adequate and explains them in a completely satisfactory way, further study is needed to find their cause, extent, and impact on surface ozone and on regional ozone budget. Any explanation, however, should explain the fairly frequent occurrence of these oscillations (on at least four nights during BAQS-Met). 

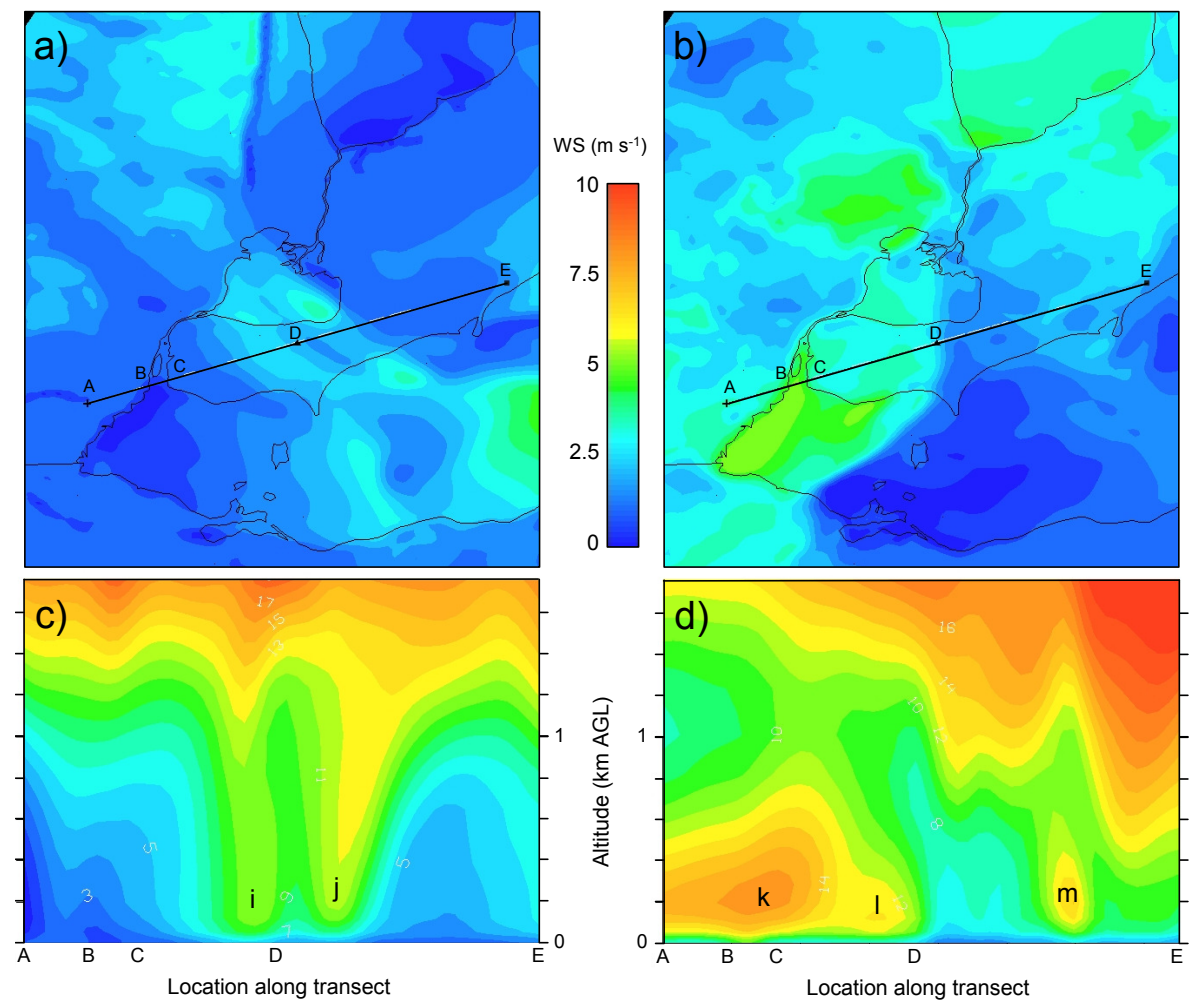

Fig. 13. Plan view at the surface $(\mathbf{a}, \mathbf{b})$ and vertical cross sections $(\mathbf{c}, \mathbf{d})$ of wind speed from the AURAMS model on the night of 6-7 July 2007 at 22:00 EDT (a, c) and 03:20 EDT (b, d).

\section{Conclusions}

Average ozone mixing ratio from the entire BAQS-Met intensive campaign period (20 June to 10 July 2007), both from ground-level observations and from AURAMS model output, support previous findings that near-surface ozone levels are higher over the southern Great Lakes than over the surrounding land. During the night and early morning, average ozone mixing ratios over the lake are $\sim 15 \mathrm{ppbv}$ higher than over rural sites and $\sim 25$ ppbv higher than over urban sites. Vertical profiles taken over land and over the lakes, as well as differences in the average diurnal change rates of ozone over lake, rural, and urban surfaces and model simulations suggest that the higher ozone levels observed over the larger lakes are limited to a shallow layer of about $200 \mathrm{~m}$ depth. Differences in $\mathrm{NO}_{\mathrm{x}}$ emissions/titration and ozone deposition velocities between land and water have a significant impact on ozone concentration contrasts between the two surfaces at night, and result in the higher ozone levels observed over water in the early morning. As soon as vertical mixing begins in the morning, ozone levels over land increase rapidly, and match the lake levels by 10:00 a.m. local time, so that in late morning until just after noon very little difference is observed. Just after noon, however, ozone levels over the lake are higher again by about 5 and $15 \mathrm{ppbv}$ compared to rural and urban sites, respectively, as seen in both observations and model results.
Model simulations over the region show great spatial heterogeneity in ozone levels over the lakes, particularly over Lake Erie with higher levels over the southwestern end of the lake. Some of this heterogeneity is due to multiple emission sources in the region that are concentrated around southwestern Lake Erie, such as large urban centers (e.g., Windsor, Detroit, Toledo, Cleveland). Another important cause of the heterogeneity in ozone over Lake Erie as well as the land areas in the region is the complex meteorology. Land and lake breezes from the different lakes, which form on the majority of days, interact with the larger-scale synoptic flow, as demonstrated for the 6-7 July 2007 case study. These complex flows transport ozone and its precursors over the region, including from emission sources to the lakes. The pollutants that are stored in the stable atmosphere over the lakes at night experience limited fresh emissions and little removal by dry deposition. Comparison of modeled and measured ozone diurnal changes over the lake at night indicates that the model simulates these processes reasonably well, with no evidence that it is over-predicting nocturnal ozone levels over the lake. When the lake breeze starts blowing towards the land in the morning, a significant increase in ozone may then be observed over land. Values as high as $90 \mathrm{ppbv}$ were observed during BAQS-Met over extreme southwestern Ontario. 
When primary air pollutants that are ozone precursors (e.g., $\mathrm{CO}, \mathrm{NO}_{\mathrm{x}}$ ) also accumulate within shallow layers and in distinct pockets over the lakes at night (e.g., northwest Lake Erie), enhanced ozone formation occurs on the next day. This process can lead to local emissions having a greater local impact (i.e., within $50 \mathrm{~km}$ ) on surface ozone mixing ratios. The case study presented for 6-7 July 2007, shows that these situations, with enhanced levels of locally-emitted precursors, are distinct from other cases of higher ozone over the lake when the accumulation of ozone has occurred over multiple days so that the available precursors have been depleted and the mixing ratio in ozone ceases to increase. The analysis also illustrates how the combination of multiple terrainforced mesoscale circulations and a heterogeneous distribution of pollutant emissions results in a patchwork of chemical air masses even within a single synoptic-scale meteorological air mass.

Considerable differences in temperature and ozone levels are observed in the vertical over land and over water in the early morning hours. While a surface inversion over land causes low ozone levels close to the surface (particularly over urban areas where mixing ratios can approach $0 \mathrm{ppbv}$ ), there is a rapid increase to regional levels above the inversion layer. In contrast, over the lake, ozone mixing ratios are fairly constant below the inversion up to $200 \mathrm{~m}$ a.g.l. but then rapidly increase to regional levels above the inversion layer. These differences in the vertical profile result in higher ozone levels over the lake at the lowest layers near the surface, but lower just below the inversion layer.

The mean ozone mixing ratios of the AURAMS model simulation for the entire study period show an ozone reservoir layer at night over Lake Erie, extending to the land over Cleveland, which is centered between $600-1000 \mathrm{~m}$ a.g.l. However, by early morning the vertical differences in ozone between over land and over lake are limited to a shallow layer of about $200 \mathrm{~m}$ a.g.l., suggesting that nighttime lake-land differences in surface ozone observed in this and previous studies have a limited effect on the overall ozone budget during the day. A different pattern is predicted by the model for Lake St. Clair, with mean vertical wind ascending over Detroit-Windsor and descending over Lake St. Clair during the day. The vertical circulation transports ozone and its precursors up to $1500 \mathrm{~m}$ a.g.l., resulting in high ozone levels in the entire column.

The high temporal resolution of the measurements examined in this study allowed the observation of nocturnal oscillations in ozone. These were recorded on several nights, and covered a relatively large spatial domain. Possible explanations for this phenomenon include intermittent turbulence that injects ozone-rich air from higher levels to the surface, the dynamics related to a lake-front progression, and lateral on-shore intrusions of ozone-rich Lake Erie air. If these oscillations are indeed the result of intermittent turbulence and injection of ozone from the residual layer aloft, they also suggest spatial heterogeneity in ozone levels in that layer. Fur- ther study is needed to establish the mechanism causing this behavior and determine the impact of such oscillations on ground-level ozone and the regional ozone budget, examining their spatial extent and frequency.

Acknowledgements. The authors acknowledge with thanks the many BAQS-Met data providers, including the Ontario Ministry of the Environment for the measurements conducted at Ridgetown and on Pelee Island, the researchers from the University of Toronto and York University for the measurements at Harrow and Ridgeotwn, the Owen Sound Transportation Company for use of their MV Jiimaan ferry and the National Research Council of Canada for the instrumented Twin Otter aircraft. Special thanks are due to Frank Froude for the tethersonde data, Andrew Sheppard for the IADN buoy data, Tomasz Stapf for operating the mesonet sites, Kurt Anlauf and Jason O'Brien for their effort with the Twin Otter $\mathrm{O}_{3}$ and $\mathrm{NO}_{2}$ measurements and Sangeeta Sharma for assistance with measurements from the MV Jiimaan. Finally, Ilan Levy gratefully acknowledges support by a post-doctoral fellowship from the Environment and Health Fund, Jerusalem, Israel.

Edited by: R. McLaren

\section{References}

Alper-Siman Tov, D., Peleg, M., Matveev, V., Mahrer, Y., Seter, I., and Luria, M.: Recirculation of polluted air masses over the East Mediterranean coast, Atmos. Environ., 31(10), 1441-1448, 1997.

Alpert, P. and Getenio, B.: One-Level Diagnostic Modeling of Mesoscale Surface Winds in Complex Terrain .Part 1. Comparison with 3-dimensional modeling in Israel, Mon. Weather Rev., 116(10), 2025-2046, 1988.

Anlauf, K., Lusis, M., Wiebe, H. and Stevens, R.: High ozone concentrations measured in the vicinity of Toronto, Canada, Atmos. Environ. (1967), 9(12), 1137-1139, doi:10.1016/00046981(75)90193-6, 1975.

Banta, R. M., Seniff, C. J., Nielsen-Gammon, J., Darby, L. S., Ryerson, T. B., Alvarez, R. J., Sandberg, S. R., Williams, E. J., and Trainer, M.: A bad air day in Houston, Bull.Amer. Meteor. Soc., 86(5), 657-669, 2005.

Brook, J. R., Strawbridge, K. B., Snyder, B. J., Boudries, H., Worsnop, D., Sharma, S., Anlauf, K., Lu, G., and Hayden, K.: Towards an understanding of the fine particle variations in the LFV: integration of chemical, physical and meteorological observations, Atmos. Environ., 38(34), 5775-5788, 2004.

Capps, S. L., Hu, Y., and Russell, A. G.: Assessing near-field and downwind impacts of reactivity-based substitutions, J. Air Waste Manag. Assoc., 60(3), 316-327, 2010.

Cheng, W.: Ozone distribution in coastal central Taiwan under sea-breeze conditions, Atmos. Environ., 36(21), 3445-3459, doi:10.1016/S1352-2310(02)00307-2, 2002.

Cho, S., Makar, P., Lee, W., Herage, T., Liggio, J., Li, S., Wiens, B., and Graham, L.: Evaluation of a unified regional airquality modeling system (AURAMS) using PrAIRie2005 field study data: The effects of emissions data accuracy on particle sulphate predictions, Atmos. Environ., 43(11), 1864-1877, doi:10.1016/j.atmosenv.2008.12.048, 2009. 
Cooper, O. R., Moody, J. L., Thornberry, T. D., Town, M. S., and Carroll, M. A.: PROPHET 1998 meteorological overview and air-mass classification, J. Geophys. Res., 106, 24289-24300, 2001.

Corsmeier, U., Kalthoff, N., Kolle, O., Kotzian, M., and Fiedler, F.: Ozone concentration jump in the stable nocturnal boundary layer during a LLJ-event, Atmos. Environ., 31(13), 1977-1989, doi:10.1016/S1352-2310(96)00358-5, 1997.

Côté, J., Gravel, S., Méthot, A., Patoine, A., Roch, M., and Staniforth, A.: The operational CMC-MRB global environmental multiscale (GEM) model. Part I: Design considerations and formulation, Mon. Weather Rev., 126(6), 1373-1395, 1998.

Drobinski, P., Saïd, F., Ancellet, G., Arteta, J., Augustin, P., Bastin, S., Brut, A., Caccia, J. L., Campistron, B., Cautenet, S., Colette, A., et al.: Regional transport and dilution during high-pollution episodes in southern France: Summary of findings from the Field Experiment to Constraint Models of Atmospheric Pollution and Emissions Transport (ESCOMPTE), J. Geophys. Res., 112, 26 pp., doi:200710.1029/2006JD007494, 2007.

Dye, T. S., Roberts, P. T., and Korc, M. E.: Observations of Transport Processes for Ozone and Ozone Precursors during the 1991 Lake Michigan Ozone Study, J. Appl. Meteor., 34(8), 18771889, 1995.

Fast, J. D. and Heilman, W. E.: The Effect of Lake Temperatures and Emissions on Ozone Exposure in the Western Great Lakes region, J. Appl. Meteor., 42(9), 1197-1217, 2003.

Fast, J. D. and Heilman, W. E.: Simulated sensitivity of seasonal ozone exposure in the Great Lakes region to changes in anthropogenic emissions in the presence of interannual variability, Atmos. Environ., 39(29), 5291-5306, doi:10.1016/j.atmosenv.2005.05.032, 2005.

Gouw, J. D. and Warneke, C.: Measurements of volatile organic compounds in the earth's atmosphere using proton-transferreaction mass spectrometry, Mass Spectrom. Rev., 26(2), 223 257, doi:10.1002/mas.20119, 2007.

Halla, J., Wagner, T., Beirle, S., Ng, A., Strawbridge, K., Firanski, B., Brook, J., Makar, P. A., and McLaren, R.: Determination of Vertical Columns of NO2 and Aerosol Optical Properties in a Rural Setting Using MAX-DOAS, to be submitted to Atmos. Chem. Phys. Discuss., 2010.

Hanna, S. R. and Chang, J. C.: Relations between meteorology and ozone in the Lake Michigan region, J. Appl. Meteor., 34(3), 670678, 1995.

Hastie, D. R., Narayan, J., Schiller, C., Niki, H., Shepson, P. B., Sills, D. M. L., Taylor, P. A., Moroz, W. J., Drummond, J. W., Reid, N., Taylor, R., Roussel, P. B., and Melo, O. T.: Observational evidence for the impact of the lake breeze circulation on ozone concentrations in Southern Ontario, Atmos. Environ., 33(2), 323-335, doi:10.1016/S1352-2310(98)00199-X, 1999.

Hayden, K., Sills, D. M. L., Li, S., Brook, J., Anlauf, K. G., O'Brien, J., and Sharma, S.: The impact of lake breezes on trace gases and particles during the Border Air Quality and Meteorology Study (BAQS-Met), to be submitted to Atmos. Chem. Phys. Discuss., 2010.

Kallos, G., Kassomenos, P. and Pielke, R. A.: Synoptic and Mesoscale Weather Conditions During Air-Pollution Episodes in Athens, Greece, Bound.-Lay. Meteorol., 62(1-4), 163-184, 1993.

Kambezidis, H. D., Weidauer, D., Melas, D., and Ulbricht, M.:
Air quality in the Athens basin during sea breeze and non-sea breeze days using laser-remote-sensing technique, Atmos. Environ., 32(12), 2173-2182, doi:10.1016/S1352-2310(97)00409-3, 1998.

Keeler, G. J., Spengler, J. D., Koutrakis, P., Allen, G. A., Raizenne, M., and Stern, B.: Transported acid aerosols measured in southern Ontario, Atmos. Environ. Part A., 24(12), 2935-2950, doi:10.1016/0960-1686(90)90474-2, 1990.

Kleinman, L. I., Daum, P. H., Imre, D., Lee, Y., Nunnermacker, L. J., Springston, S. R., Weinstein-Lloyd, J., and Rudolph, J.: Ozone production rate and hydrocarbon reactivity in 5 urban areas: A cause of high ozone concentration in Houston, Geophys. Res. Lett., 29(10), 1467, doi:10.1029/2001GL014569, 2002.

Lasry, F., Coll, I., and Buisson, E.: An insight into the formation of severe ozone episodes: modeling the 21/03/01 event in the ESCOMPTE region, Atmospheric Research, 74(1-4), 191-215, 2005.

Levy, I., Dayan, U., and Mahrer, Y.: A five-year study of coastal recirculation and its effect on air pollutants over the East Mediterranean region, J. Geophys. Res.-Atmos., 113(D16), D16121, doi:10.1029/2007JD009529, 2008a.

Levy, I., Dayan, U., and Mahrer, Y.: Studying coastal recirculation with a simplified analytical land-sea breeze model, J. Geophys. Res.-Atmos., 113, D3104, doi:10.1029/2007JD008628, 2008 b.

Liu, K., Wang, Z., and Hsiao, L.: A modeling of the sea breeze and its impacts on ozone distribution in northern Taiwan, Environ. Modell. Softw., 17(1), 21-27, doi:10.1016/S13648152(01)00049-4, 2002.

Lu, R. and Turco, R. P.: Air Pollutant Transport in a Coastal Environment .1. 2-Dimensional Simulations of Sea-Breeze and Mountain Effects, J. Atmos. Sci., 51(15), 2285-2308, 1994.

Lu, R. and Turco, R. P.: Air Pollutant Transport in a Coastal Environment 2. 3-Dimensional Simulations over Los-Angeles basin, Atmos. Environ., 29(13), 1499-1518, 1995.

Lyons, W. A. and Cole, H. S.: Fumigation and Plume Trapping on the Shores of Lake Michigan During Stable Onshore Flow, J. Appl. Meteor., 12(3), 494-510, 1973.

Lyons, W. A. and Cole, H. S.: Photochemical Oxidant Transport - Mesoscale Lake Breeze and Synoptic-Scale Aspects, J. Appl. Meteor., 15(7), 733-743, 1976.

Makar, P. A., Moran, M. D., Zheng, Q., Cousineau, S., Sassi, M., Duhamel, A., Besner, M., Davignon, D., Crevier, L.-P., and Bouchet, V. S.: Modelling the impacts of ammonia emissions reductions on North American air quality, Atmos. Chem. Phys., 9, 7183-7212, doi:10.5194/acp-9-7183-2009, 2009.

Makar, P. A., Gong, W., Mooney, C., Zhang, J., Davignon, D., Samaali, M., Moran, M. D., He, H., Tarasick, D. W., Sills, D., and Chen, J.: Dynamic adjustment of climatological ozone boundary conditions for air-quality forecasts, Atmos. Chem. Phys., 10, 8997-9015, doi:10.5194/acp-10-8997-2010, 2010a.

Makar, P., Zhang, J., Gong, W. M., Stroud, C., Sills, D. M. L., Hayden, K., Brook, J. R., Levy, I., Mihele, C., Moran, M. and Tarasick, D.: Mass tracking for chemical analysis: the causes of ozone formation in southern Ontario during BAQS-Met 2007, Atmos. Chem. Phys., in press, 2010b.

Mavrakis, A., Flocas, H. A., Mavromatidis, E., Kallos, G., Theoharatos, G. and Christides, A.: A case of nighttime high ozone concentration over the greater Athens area, Meteorol. Z., 19, 3545, doi:10.1127/0941-2948/2010/0428, 2010. 
Millan, M. M., Mantilla, E., Salvador, R., Carratala, A., Sanz, M. J., Alonso, L., Gangoiti, G., and Navazo, M.: Ozone cycles in the western Mediterranean basin: Interpretation of monitoring data in complex coastal terrain, J. Appl. Meteor., 39(4), 487-508, 2000.

Mukammal, E. I.: Ozone as a cause of tobacco injury, Agric. Meteor., 2(3), 145-165, doi:10.1016/0002-1571(65)90016-6, 1965.

Murray, D., McWhirter, J., Wier, S., and Emmerson, S.: The Integrated Data Viewer: a web-enabled application for scientific analysis and visualization, in Preprints, 19th Conference on Interactive Information Processing Systems (IIPS) for Meteorology, Oceanography, and Hydrology, p. 13.2. American Meteorological Society, Boston, February 2003

Oh, I., Kim, Y., Lee, H. W., and Kim, C.: An observational and numerical study of the effects of the late sea breeze on ozone distributions in the Busan metropolitan area, Korea, Atmos. Environ., 40(7), 1284-1298, 2006.

Ohashi, Y. and Kida, H.: Local circulations developed in the vicinity of both coastal and inland urban areas: A numerical study with a mesoscale atmospheric model, J. Appl. Meteor., 41(1), 30-45, 2002.

RDCT: (R Development Core Team): A Language and Environment for Statistical Computing, R Foundation for Statistical Computing, Vienna, Austria, available online at: http://www. R-project.org, 2009.

Reitebuch, O., Strassburger, A., Emeis, S., and Kuttler, W.: Nocturnal secondary ozone concentration maxima analysed by sodar observations and surface measurements, Atmos. Environ., 34(25), 4315-4329, doi:10.1016/S1352-2310(00)00185-0, 2000.

Roberts, J. M., Fehsenfeld, F. C., Liu, S. C., Bollinger, M. J., Hahn, C., Albritton, D. L., and Sievers, R. E.: Measurements of aromatic hydrocarbon ratios and $\mathrm{NO}_{\mathrm{x}}$ concentrations in the rural troposphere: Observation of air mass photochemical aging and $\mathrm{NO}_{\mathrm{x}}$ removal, Atmos. Environ., 18(11), 2421-2432, doi:10.1016/0004-6981(84)90012-X, 1984.
Salmond, J. A. and McKendry, I. G.: Secondary ozone maxima in a very stable nocturnal boundary layer: Observations from the Lower Fraser Valley, BC, Atmos. Environ., 36(38), 5771-5782, 2002.

Salmond, J. A. and McKendry, I. G.: A review of turbulence in the very stable nocturnal boundary layer and its implications for air quality, Prog. Phys. Geog., 29(2), $171-188$, doi:10.1191/0309133305pp442ra, 2005.

Sillman, S., Samson, P. J., and Masters, J. M.: Ozone Production in Urban Plumes Transported Over Water: Photochemical Model and Case Studies in the Northeastern and Midwestern United States, J. Geophys. Res., 98(D7), 12687-12699, doi:199310.1029/93JD00159, 1993.

Sills, D. M. L., Brook, J., Taylor, P., Junhua, Z., Levy, I., Makar, P. and Hayden, K.: Lake Breezes in the Southern Great Lakes and Their Influence During BAQS-Met 2007, to be submitted to Atmos. Chem. Phys. Discuss., 2010.

Stroud, C., Makar, P., Moran, M., Gong, W. M., Gong, S., Zhang, J., Hayden, K., Mihele, C., Brook, J., Abbatt, J. and Slowik, J.: Impact of model grid spacing on regional air quality predictions of organic aerosol, Atmos. Chem. Phys. Discuss., submitted, 2010.

Sun, J., Burns, S. P., Lenschow, D. H., Banta, R., Newsom, R., Coulter, R., Frasier, S., Ince, T., Nappo, C., Cuxart, J., Blumen, W. et al.: Intermittent Turbulence Associated with a Density Current Passage in the Stable Boundary Layer, Bound.-Lay. Meteor., 105(2), 199-219, doi:10.1023/A:1019969131774, 2002.

Vlasenko, A., Slowik, J. G., Bottenheim, J. W., Brickell, P. C., Chang, R. Y., Macdonald, A. M., Shantz, N. C., Sjostedt, S. J., Wiebe, H. A., Leaitch, W. R., and Abbatt, J. P. D.: Measurements of VOCs by proton transfer reaction mass spectrometry at a rural Ontario site: Sources and correlation to aerosol composition, J. Geophys. Res., 114(D21), D21305, doi:10.1029/2009JD012025, 2009.

Zhang, J. and Rao, S. T.: The Role of Vertical Mixing in the Temporal Evolution of Ground-Level Ozone Concentrations, J. Appl. Meteor., 38(12), 1674-1691, 1999. 